\title{
A Decade of Ocean Changes Impacting the Ice Shelf of Petermann Gletscher, Greenland
}

\author{
P. WASHAM AND A. MÜNCHOW \\ College of Earth, Ocean, and Environment, University of Delaware, Newark, Delaware \\ K. W. NICHOLLS \\ British Antarctic Survey, Natural Environment Research Council, Cambridge, United Kingdom
}

(Manuscript received 13 September 2017, in final form 28 August 2018)

\begin{abstract}
Hydrographic data collected during five summer surveys between 2002 and 2015 reveal that the subsurface ocean near Petermann Gletscher, Greenland, warmed by $0.015^{\circ} \pm 0.013^{\circ} \mathrm{C} \mathrm{yr}^{-1}$. New $2015-16$ mooring data from beneath Petermann Gletscher's ice shelf imply a continued warming of $0.025^{\circ} \pm 0.013^{\circ} \mathrm{C} \mathrm{yr}^{-1}$ with a modest seasonal signal. In 2015 , we measured ocean temperatures of $0.28^{\circ} \mathrm{C}$ near the grounding line of Petermann Gletscher's ice shelf, which drove submarine melting along the base of the glacier. The resultant meltwater contributed to ocean stratification, which forced a stronger geostrophic circulation at the ice shelf terminus compared with previous years. This increased both the freshwater flux away from the sub-ice shelf cavity and the heat flux into it. Net summertime geostrophic heat flux estimates into the sub-ice shelf cavity exceed the requirement for steady-state melting of Petermann Gletscher's ice shelf. Likewise, freshwater fluxes away from the glacier exceed the expected steady-state meltwater discharge. These results suggest that the warmer, more active ocean surrounding Petermann Gletscher forces "non steady state" melting of its ice shelf. When sustained, such melting thins the ice shelf.
\end{abstract}

\section{Introduction}

The Greenland Ice Sheet currently experiences heightened mass loss, both from acceleration of its marineterminating outlet glaciers and from enhanced summer surface melt (Rignot and Kanagaratnam 2006; van den Broeke et al. 2009; Enderlin et al. 2014). The acceleration of Greenland's outlet glaciers has been linked to ocean warming at their marine termini (Bindschadler 2006; Holland et al. 2008; Straneo and Heimbach 2013; Mouginot et al. 2015). Two prominent examples of major Greenland outlet glaciers undergoing dramatic losses are Jakobshavn Isbrae and Zachariae Isstrom. Following a warming of the nearby subsurface ocean, both glaciers quickly lost their floating ice shelf, then began to retreat along a downward-sloping bed and accelerate (Holland et al. 2008; Mouginot et al. 2015).

Straneo and Cenedese (2015) recently summarized the dynamics within Greenland's glacial fjords, which connect its marine-terminating outlet glaciers to the

Corresponding author: P. Washam, pwasham@udel.edu surrounding continental shelves. The continental shelves around Greenland contain two distinct water masses: cold and freshwater of Arctic origin [Polar water (PW)] near the surface and warm and salty water of Atlantic origin [Atlantic water (AW)] at depth. A halocline separates the lighter PW exiting the Arctic Ocean from the dense AW circulating in the deep basins surrounding Greenland (Aagaard et al. 1981; Holland et al. 2008; Rignot et al. 2010; Straneo et al. 2010; Christoffersen et al. 2011). Greenland's largest outlet glaciers terminate in fjords with deep sills that allow both PW and AW to enter from the adjacent continental shelf. Warm AW forms the deep water column of these fjords where pressure lowers the local freezing point of seawater (Hansen 1904; Fujino et al. 1974). This raises the AW temperature relative to the in situ freezing point and further increases its capacity to drive rapid submarine melting at the glacier's marine termini. When sustained, this rapid melting has profound effects on the glacier, as seen with Jakobshavn Isbrae and Zachariae Isstrom (Holland et al. 2008; Mouginot et al. 2015). Over a 10 -yr period, stronger submarine melting by warmer AW dismantled each 


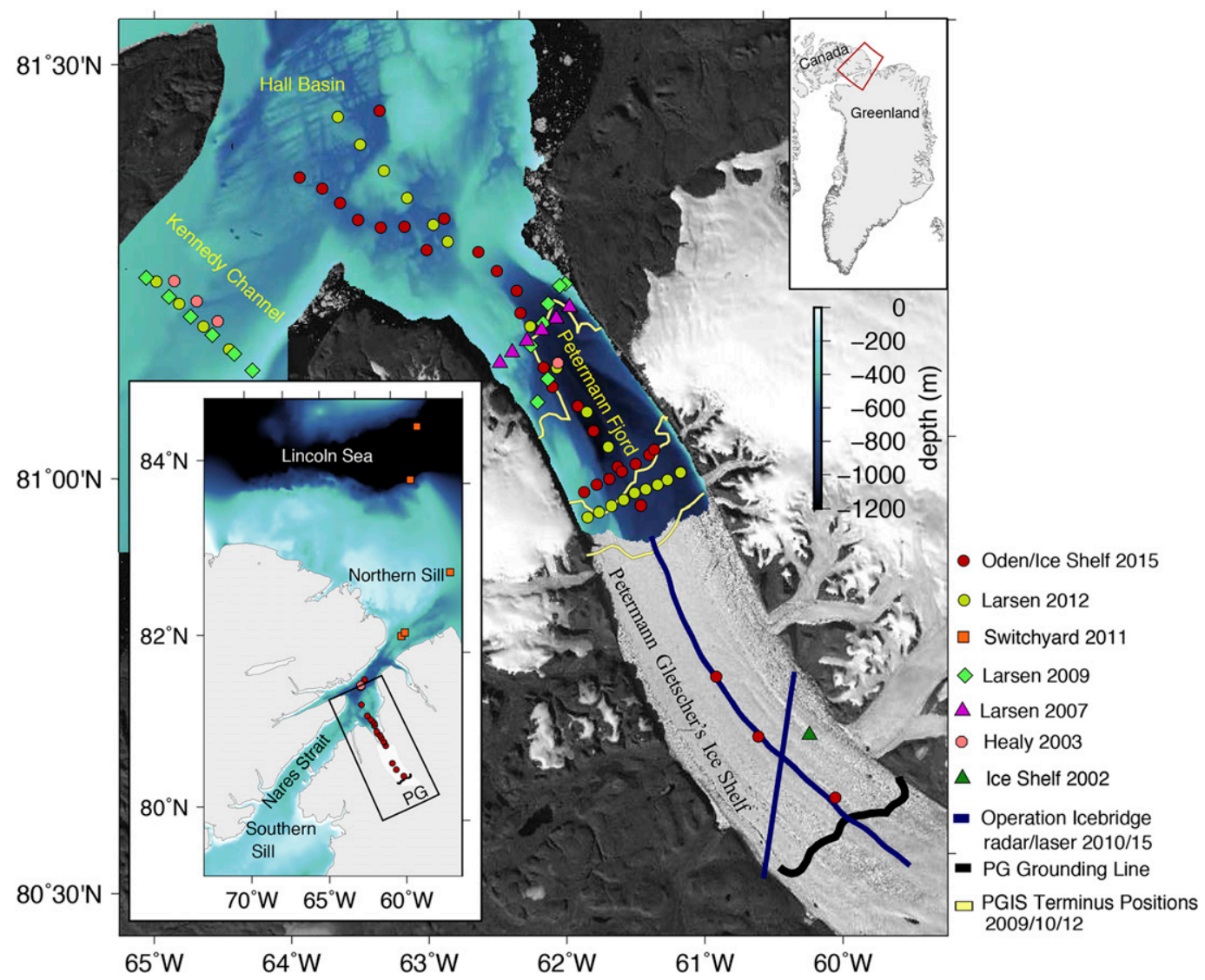

FIG. 1. Data stations used in this study from Petermann Gletscher, Petermann Fjord, Nares Strait, and the Lincoln Sea. Insets display the larger area surrounding the study region. The central figure is a 2015 Landsat-8 image of Petermann Gletscher and the ocean nearby with bathymetry from the 2015 Oden research cruise overlayed. Bathymetry outside of this geographic region comes from the IBCAO 3 data product.

glacier's $\sim 40$-km-long ice shelf. The glaciers now terminate into the ocean as tidewater glaciers that more readily calve as they are undercut by submarine melting deep below the waterline.

Submarine melting of a glacier releases freshwater into the fjord, which drives a buoyant flow analogous to the classic two-layer estuarine circulation described by Farmer and Freeland (1983). This classic circulation characterizes flow in nonglacial fjords where surface freshwater released at the head of the fjord overlays dense seawater. Winds, tides, and other processes turbulently mix the outflowing freshwater downward, entraining some underlying seawater. The mixture of freshwater and seawater creates a mass imbalance when it exits the fjord that must be compensated by a deep inflow of seawater to the fjord. A glacier releases buoyant freshwater both at depth (submarine melting and subglacial discharge at the grounding line) and at the surface (summer surface runoff). This creates a multilayer circulation in Greenland's glacial fjords with a deep inflow of AW past the sill superimposed by freshwater-enriched outflow at shallow and middepths (Mortensen et al. 2011; Straneo et al. 2011). Earth's rotation will produce across-fjord variations in this circulation if the width of the fjord exceeds the internal deformation radius. Johnson et al. (2011) reported such flow in Petermann Fjord, which is $\sim 15 \mathrm{~km}$ wide and has an internal deformation radius of $\sim 7 \mathrm{~km}$ (Fig. 1).

Petermann Gletscher is a large northwestern Greenland outlet glacier that drains $4 \%$ of the Greenland Ice Sheet and terminates in Petermann Fjord (Rignot et al. 2001). Major calving events in 2010 and 2012 reduced the length of Petermann Gletscher's ice shelf (PGIS) from 81 to $48 \mathrm{~km}$ (Johnson et al. 2011; Nick et al. 2013). Münchow et al. (2014) documented structural changes in PGIS for the decade leading up to these events. After analyzing repeat track glacier elevation surveys, they discovered that PGIS thinned by $3-5 \mathrm{~m} \mathrm{yr}^{-1}$ for the 2003-10 period (Münchow et al. 2014). Stronger oceanforced submarine melting along the ice shelf base likely 
produced this thinning, as it accounts for the majority of PGIS mass loss (Rignot and Steffen 2008). Glacier speeds remained steady at $1.05 \mathrm{~km} \mathrm{yr}^{-1}$ prior to 2010 , but increased by $12 \%$ to $1.18 \mathrm{~km} \mathrm{yr}^{-1}$ after the 2010 and 2012 calving events (Münchow et al. 2016). In its current state, PGIS occupies an area of $900 \mathrm{~km}^{2}$, retains a mean ice thickness of $\sim 300 \mathrm{~m}$, and grounds $\sim 600 \mathrm{~m}$ below sea level (Münchow et al. 2014). The bedrock elevation increases upstream of the PGIS grounding line, suggesting that this grounding line is dynamically stable (Hogg et al. 2016).

A 440-m-deep sill separates the 1100-m-deep Petermann Fjord, where PGIS terminates, from the adjoining Hall Basin (Fig. 1) (Johnson et al. 2011). Hall Basin is a deep section of the 500-km-long Nares Strait, which separates Greenland from the Canadian Archipelago and connects the Lincoln Sea of the Arctic Ocean to the Atlantic Ocean via Baffin Bay (Fig. 1 inset). Nares Strait is a pathway for freshwater exiting the Arctic Ocean in the form of PW and sea ice (de Steur et al. 2013; Dunbar 1973; Münchow et al. 2016; Sadler 1976). Sea ice flow through Nares Strait stops seasonally when an ice arch forms across its southern branch (Kwok 2005). During some years, the ice arch fails to form, which allows for yearlong sea ice flow (Ryan and Münchow 2017). Two sills prevent direct deep water passage through Nares Strait. A northern sill at $290 \mathrm{~m}$ inhibits the flow of deep AW from the Lincoln Sea to Nares Strait, and a 220-mdeep southern sill prevents AW inflow from Baffin Bay (Fig. 1 inset; see also Münchow et al. 2011). Nonetheless, Münchow et al. (2011) detected a water mass in Nares Strait with temperature-salinity $(T-S)$ characteristics similar to the AW found in the Lincoln Sea to the north. Furthermore, they found warming in the Nares Strait bottom water that coincided with the arrival of warmer AW to the Lincoln Sea in 2004 (de Steur et al. 2013).

Johnson et al. (2011) confirmed the presence of AW in Nares Strait using summertime conductivity-temperaturedepth (CTD) profiles collected prior to the PGIS calving events. They found that AW fills Hall Basin, then spills over the sill into Petermann Fjord, where it occupies the lower water column. Higher in the Petermann Fjord water column, they identified water with a $T-S$ relationship and dissolved oxygen content characteristic of submarine melting by this AW. Münchow et al. (2016) investigated 6 months of ocean time series from sensors moored below PGIS after the two large calving events. They identified fortnightly pulses in temperature and salinity near the ice base, which suggested a regular thickening of the under-ice mixed layer. The authors speculated that these pulses result from the spring-neap tidal cycle modulating submarine melting and the associated advection of glacial meltwater below PGIS. A modeling effort by Cai et al. (2017) revealed that during the warm summer months, increased subglacial freshwater discharged across the glacier's grounding line can enhance maximum submarine melting below PGIS by a factor of 2 . Shroyer et al. (2017) also found that during summer, a mobile sea ice state in Nares Strait increased modeled submarine melt rates beneath the outer portion of PGIS by $20 \%$. Heuzé et al. (2017) tracked glacial meltwater through Petermann Fjord using CTD profiles from 2015 and found that it exits the fjord at shallow and middepths along the northeast side. A deep inflow of AW along the southwest side of the fjord compensates for this outflow. The estimated net horizontal heat flux associated with this inflow exceeds the requirement for steady-state melting of PGIS (Johnson et al. 2011; Heuzé et al. 2017).

Johnson et al. (2011) and Heuzé et al. (2017) focused on the interaction between Petermann Fjord and Nares Strait during a single summer. We here extend their studies in time and space to address interannual ocean changes that impact PGIS. We do this by first establishing a connection between Petermann Fjord and the Lincoln Sea, then discussing ocean variability from 2002 to 2016 near PGIS caused by the inflow of warmer AW from the Lincoln Sea. Next, we investigate changes in ocean circulation at the PGIS terminus using geostrophic velocities from 2007, 2009, 2012, and 2015 CTD sections. Following this, we examine full CTD profiles taken below PGIS and analyze the water masses present. Finally, we estimate geostrophic heat and freshwater fluxes from the PGIS terminus sections to identify coupled changes in ocean temperature, salinity, and circulation.

\section{Data and methods}

\section{a. CTD data}

Figure 1 displays the locations of CTD data included in this study overlaid on 2015 Landsat-8 imagery of Petermann Gletscher and the nearby ocean. In the summer of 2015, we drilled three access holes through PGIS with the British Antarctic Survey's hot water drill (Makinson and Anker 2014). We then collected CTD profiles in the sub-ice shelf cavity at locations 3,13, and $26 \mathrm{~km}$ seaward of the grounding line. We retrieved these profiles with a lightweight Sea-Bird SBE 49 FastCAT CTD sensor that sampled temperature, conductivity, and pressure at $16 \mathrm{~Hz}$. The instrument was calibrated prior to field use on 9 June 2015. CTD profiles were processed with the Sea-Bird Scientific software package. Data were low-pass filtered with temperature and conductivity measurements aligned to account for different sensor response times. We corrected for thermal mass errors produced when the conductivity sensor traversed 
TABLE 1. Multiyear CTD data. Note that uncertainty values come from inspection of CTD and mooring data and compare well with factory settings. Processing codes are as follows—a: Data Conversion, b: Low-pass filter, c: Align CTD, d: Cell Thermal Mass, e: Loop Edit, f: Derive Vars, and g: Bin Avg (bin size). Asterisk indicates CT alignment by deck.

\begin{tabular}{|c|c|c|c|c|c|c|c|}
\hline Year & & Instrument & $\begin{array}{c}\text { Calibration } \\
\text { date }\end{array}$ & $\begin{array}{l}\text { Sampling } \\
\text { rate }(\mathrm{Hz})\end{array}$ & $\begin{array}{l}\text { Uncertainty } \\
\text { temp. }\left({ }^{\circ} \mathrm{C}\right)\end{array}$ & $\begin{array}{l}\text { Salinity } \\
\left(\mathrm{g} \mathrm{kg}^{-1}\right)\end{array}$ & $\begin{array}{l}\text { Processing } \\
\text { routines }\end{array}$ \\
\hline \multirow[t]{2}{*}{2015 Ice Shelf } & CTD & SBE 49 & Jun 2015 & 16 & \pm 0.002 & \pm 0.002 & $\mathrm{a}-\mathrm{g}(1 \mathrm{~m})$ \\
\hline & Mooring $(450 \mathrm{~m})$ & SBE 37-SM & Apr 2003 & $1 \mathrm{~h}$ & \pm 0.002 & \pm 0.004 & $\mathrm{f}$ \\
\hline 2015 Oden & & SBE $911+$ & Jul 2015 & 24 & \pm 0.001 & \pm 0.003 & $\mathrm{a}-\mathrm{g}(1 \mathrm{~m})$ \\
\hline 2012 Larsen & & SBE 25 & Jan 2008 & 8 & \pm 0.003 & \pm 0.002 & $\mathrm{a}-\mathrm{c},{ }^{*} \mathrm{~d}-\mathrm{g}(1 \mathrm{~m})$ \\
\hline \multirow[t]{2}{*}{2011 Switchyard } & Nares Strait & TSK-JP AXCTD & - & 15 & \pm 0.03 & \pm 0.04 & $\mathrm{f}$ \\
\hline & Lincoln Sea & SBE $19+$ & Jan 2011 & 4 & \pm 0.01 & \pm 0.008 & $\mathrm{a}-\mathrm{g}$ \\
\hline 2009 Larsen & & SBE 25 & Dec 2007 & 8 & \pm 0.004 & \pm 0.003 & $\mathrm{a}-\mathrm{c}, * \mathrm{~d}-\mathrm{g}(1 \mathrm{~m})$ \\
\hline 2007 Larsen & & SBE 25 & Dec 2004 & 8 & \pm 0.007 & \pm 0.004 & $\mathrm{a}-\mathrm{c}, * \mathrm{~d}-\mathrm{g}(1 \mathrm{~m})$ \\
\hline 2003 Healy & & SBE 911+ & May 2007 & 24 & \pm 0.003 & \pm 0.002 & $\mathrm{a}-\mathrm{g}(1 \mathrm{~m})$ \\
\hline 2002 Ice Shelf & & Unknown & Unknown & Unknown & \pm 0.005 & \pm 0.01 & - \\
\hline
\end{tabular}

temperature gradients, removed samples taken when the instrument moved upward, and smoothed final data by averaging them into $1-\mathrm{m}$ vertical bins.

Along with the 2015 sub-ice shelf data, we collected 46 ship-based CTD profiles in Petermann Fjord and Nares Strait from the Swedish research vessel Ice Breaker (I/B) Oden. For these, we used an SBE 911+ integrated CTD and deck unit that sampled temperature, conductivity, pressure, and dissolved oxygen at $24 \mathrm{~Hz}$. The instrument was calibrated on 17 July 2015, and data were processed in identical fashion to the ice shelf data. Table 1 lists calibration dates, instrument specifications, processing routines, and sensor uncertainties for all hydrographic data used in this study. Uncertainty values come from inspection of ocean property variance below 500-m depth in Hall Basin and Petermann Fjord, where vertical gradients are small. They compare well with factory settings.

In addition to the 2015 data, we exploit hydrographic measurements from previous summer ship-based CTD surveys in Petermann Fjord and Nares Strait. More specifically, we select CTD profiles from published datasets collected in 2003, 2007, and 2009, along with unpublished 2012 data. The 2003 measurements span from Baffin Bay to Petermann Fjord and are described by Münchow et al. (2015). The 2007 and 2009 measurements cover Nares Strait and the western entrance to Petermann Fjord (Johnson et al. 2011). The 2012 data extend from Nares Strait into the newly opened portion of Petermann Fjord exposed by the 2010 and 2012 calving events. Along with the ship-based data, we use CTD profiles collected in 2011 by the Freshwater Switchyard program in Nares Strait and the Lincoln Sea (Steele et al. 2004) and a CTD profile collected below PGIS in 2002 by Rignot and Steffen (2008).

We convert all CTD data to Conservative Temperature $\Theta$ and Absolute Salinity $S_{\mathrm{A}}$ using the International Thermodynamic Equation Of Seawater-2010 (TEOS-10;
McDougall and Barker 2011). We compare measurements from 2015 with the earlier data to investigate changes in the summer water column surrounding PGIS. The Fig. 1 inset provides locations for Nares Strait and Lincoln Sea data outside of the Landsat- 8 image swath.

\section{b. Ice shelf mooring data}

We moored nine Sea-Bird SBE 37-SM CT sensors beneath PGIS at the three 2015 drilling locations (Fig. 1). Prior to deployment, we compared these instruments with the ship-board SBE $911+$. We halted a CTD profile seven separate times for $15 \mathrm{~min}$ to compare the SBE 37-SMs and the SBE 911+. We thus derived correctional coefficients $(a, b)$ by fitting the SBE 37-SM conductivity and temperature data $x(t)$ to the SBE $911+$ data $y(t)$ with a linear regression: $y(t)=a+b x(t)$. Next, we applied these coefficients and took the difference between the SBE 37-SM data and SBE 911+ data to estimate sensor uncertainty (Table 1; see also Kanzow et al. 2006). We then installed these sensors at various depths in the sub-ice shelf cavity, connected them through conducting cables to dataloggers on the glacier surface, and equipped these dataloggers with an Iridium modem to accommodate real-time data acquisition. Here, we present time series from one of the sensors deployed at 450-m depth, $13 \mathrm{~km}$ from the grounding line. Analysis of the full dataset lies beyond the scope of this study.

\section{c. Glacier data}

NASA's Operation IceBridge has flown over Petermann Gletscher since 2002 with a DC-8 (2010), P-3 (2002, 2003, 2007, 2011-14), or C-130 (2015). The aircraft carried a multichannel ice-sounding radar, operated by the University of Kansas, to measure air-ice and ice-bedrock interfaces over the grounded glacier and air-ice and ice-ocean interfaces over the floating ice shelf. We utilize 2010 and 2015 level 2 radar data that provide interface elevations 


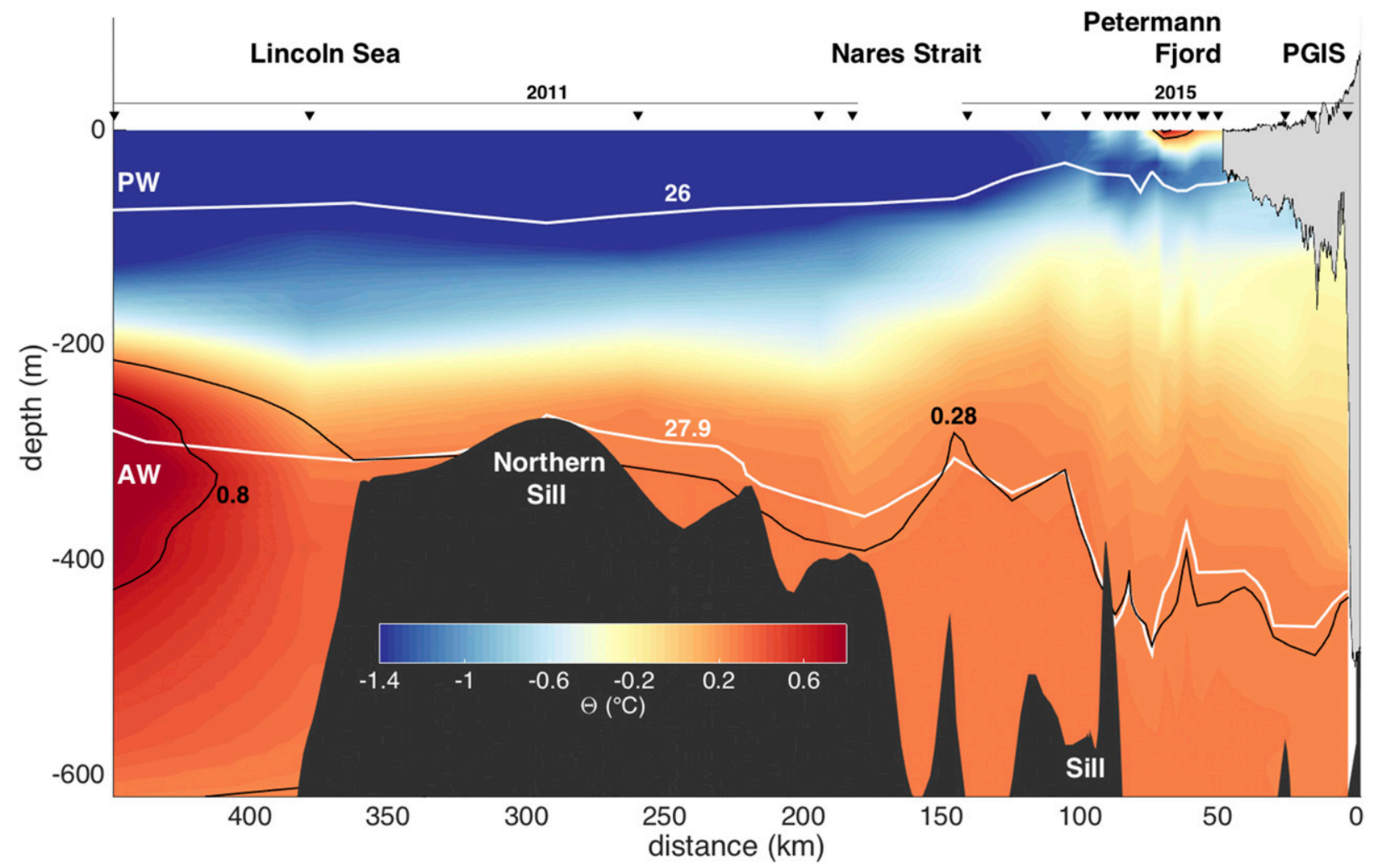

FIG. 2. Conservative Temperature section of the extended study area with selected isotherms in black and isopycnals in white. Temperature and density data out to a distance of $150 \mathrm{~km}$ come from the 2015 research expedition, and data from 180 to $450 \mathrm{~km}$ come from the 2011 Freshwater Switchyard program. The 2011 and 2015 data are linearly interpolated between these two data points. Bottom bathymetry comes from gravity cores taken beneath PGIS, multibeam data from the 2015 research expedition, and the IBCAO 3 product. Bathymetry only above $650 \mathrm{~m}$ is shown.

every $\sim 15 \mathrm{~m}$ along the flight track at a $\sim 10$-m vertical accuracy (Gogineni et al. 2001). The aircraft also carried a scanning laser altimeter to measure the ice surface. We use 2010 level 1B laser data with a horizontal resolution of $\sim 1 \mathrm{~m}$ and a vertical accuracy of $\sim 0.08 \mathrm{~m}$ (Krabill et al. 2002) and subsample it to $\sim 15-\mathrm{m}$ spacing. We convert laser data from the WGS-84 ellipsoid to the EGM2008 geoid to estimate ice freeboard from the surface elevation measurements (Pavlis et al. 2012). Figure 1 displays Operation IceBridge flight lines used in this study.

\section{Results}

\section{a. Ocean properties of the study area}

Figure 2 presents ocean Conservative Temperature $\Theta$ from the Lincoln Sea to the sub-ice shelf cavity beneath PGIS with two isopycnal surfaces that represent PW $\left(\sigma_{\Theta} \leq 26 \mathrm{~kg} \mathrm{~m}^{-3}\right)$ and AW $\left(\sigma_{\Theta} \geq 27.9 \mathrm{~kg} \mathrm{~m}^{-3}\right)$, where $\sigma_{\Theta}$ is the potential density anomaly referenced to $0 \mathrm{dbar}$ $\left(\sigma_{\Theta}=\rho_{\Theta}-1000 \mathrm{~kg} \mathrm{~m}^{-3}\right)$. We combine the $2011 \mathrm{CTD}$ data from the Lincoln Sea and Robeson Channel in the north with the 2015 CTD data collected farther south in Nares Strait, Hall Basin, Petermann Fjord, and the sub-ice shelf cavity. The locations of these measurements can be found in the Fig. 1 inset.

Cold and fresh PW dominates the upper water column from the Lincoln Sea to Petermann Fjord, where solar radiation and glacial and terrestrial freshwater runoff warms and freshens the upper ocean in summer. An underlying pycnocline separates this light upper layer $\left(\sigma_{\Theta} \leq\right.$ $26 \mathrm{~kg} \mathrm{~m}^{-3}$ ) from the water column below, where ocean temperature increases with depth. Offshore of the shelf slope in the Lincoln Sea, we identify a subsurface temperature maximum $\left(\Theta=0.8^{\circ} \mathrm{C}\right.$ and $\left.\sigma_{\Theta}=27.9 \mathrm{~kg} \mathrm{~m}^{-3}\right)$ at 315-m depth (Fig. 2). This temperature maximum is the core of the AW in the Lincoln Sea, which resides between 200- and 450-m depth and varies in temperature from $0.28^{\circ}$ to $0.8^{\circ} \mathrm{C}$ (Aagaard 1989; Carmack et al. 1997; McLaughlin et al. 2002; Rudels et al. 1994).

We find water with a similar density below $300 \mathrm{~m}$ in Nares Strait. This implies that AW flows over the northern sill from the Lincoln Sea into Nares Strait. However, the AW in Nares Strait does not represent the 

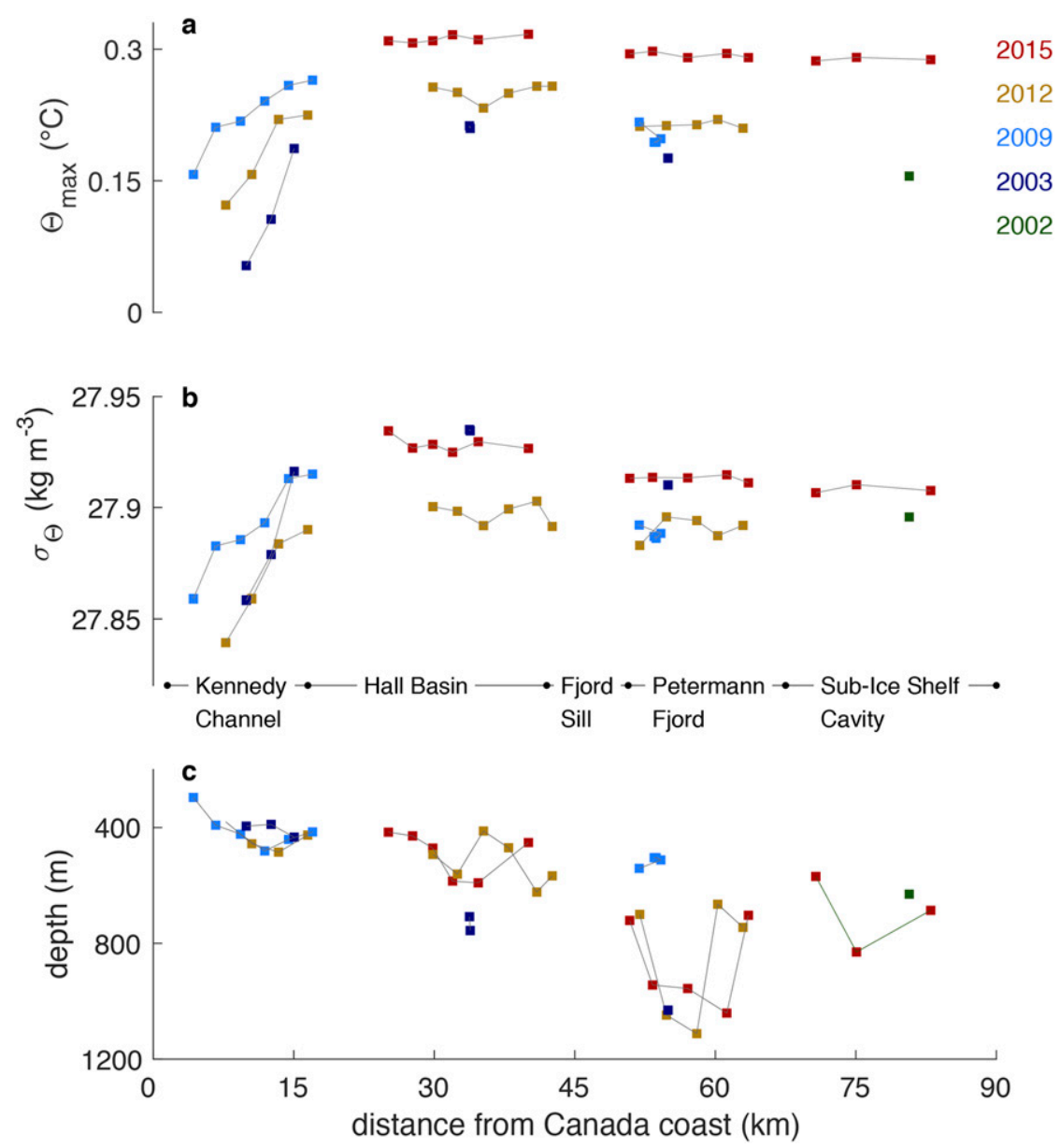

FIG. 3. (a) Temperature maxima as a function of time and location from summer CTD surveys, with the (b) associated potential density anomaly and (c) depth.

warmest water offshore in the Lincoln Sea, but instead the cooler inshore water residing near the northern sill depth. Farther south in Nares Strait, this cooler AW $\left(0.28^{\circ}-0.31^{\circ} \mathrm{C}\right)$ fills Hall Basin from $300 \mathrm{~m}$ to the seafloor. We then observe it spilling over the sill into Petermann Fjord and extending into the sub-ice shelf cavity from $\sim 500 \mathrm{~m}$ to the seafloor. As we will show later, AW with a temperature of $0.28^{\circ} \mathrm{C}$ contacts PGIS near the grounding line at $450-\mathrm{m}$ depth. While this water is $\sim 0.5^{\circ} \mathrm{C}$ cooler than the Lincoln Sea AW core, it is still warm enough to drive strong melting along the underside of PGIS.

\section{b. Ocean warming in Nares Strait and Petermann Fjord}

Several years of summer CTD data collected in Kennedy Channel, Hall Basin, Petermann Fjord, and the sub-ice shelf cavity allow us to examine deep water changes caused by AW inflow from the Lincoln Sea. To do this, we compare the subsurface temperature maxima $\Theta_{\max }$ from CTD profiles in these regions between 2002 and 2015 with their potential density anomalies $\sigma_{\Theta}$ and depths (Fig. 3).

In Kennedy Channel, we locate temperature maxima between 300- and 500-m depth for 2003, 2009, and 2012 data (Fig. 3c). We observe both warmer and denser waters in Kennedy Channel as we move eastward from the Canada coast to Greenland. This across-channel gradient persists between years, but the temperature maxima values do change. In 2003, the measured temperature maxima ranged from $0.05^{\circ}$ to $0.19^{\circ} \mathrm{C}$. The temperature maxima then increased to between $0.16^{\circ}$ and $0.26^{\circ} \mathrm{C}$ in 2009 , followed by a decrease to between $0.12^{\circ}$ and $0.22^{\circ} \mathrm{C}$ in 2012 (Fig. 3a). The corresponding density, which relates to salinity, also increased from 2003 to 2009, then decreased in 2012 (Fig. 3b).

In Hall Basin, we observe warmer temperature maxima than in Kennedy Channel for all years. These warmer waters do not vary across the channel, are 
similarly denser $\left(\sim 0.025 \mathrm{~kg} \mathrm{~m}^{-3}\right)$, and reside at greater depths (400-800 m; Figs. 3a-c). The measured Hall Basin subsurface temperature maximum increased from $0.21^{\circ} \pm 0.003^{\circ} \mathrm{C}$ in 2003 to $0.25^{\circ} \pm 0.003^{\circ} \mathrm{C}$ in 2012 and then to $0.31^{\circ} \pm 0.001^{\circ} \mathrm{C}$ in 2015 (Fig. 3a). The density of this water appeared similar in 2003 and 2015, but was $\sim 0.03 \mathrm{~kg} \mathrm{~m}^{-3}$ lower in 2012 .

The Hall Basin temperature maxima are located at depths below the Petermann Fjord sill depth. As a result, the temperature maxima measured in Petermann Fjord are $\sim 0.03^{\circ} \mathrm{C}$ cooler, $\sim 0.02 \mathrm{~kg} \mathrm{~m}^{-3}$ less dense, and reside deeper in the water column at 750-115-m depth (excluding 2009 data, which did not reach the seafloor; Figs. 3a-c). Nonetheless, we observe subsurface warming in Petermann Fjord that closely resembles the warming in Hall Basin. The 2015 temperature maxima from the sub-ice shelf cavity resemble the Petermann Fjord temperature maxima and indicate transport of these warm waters beneath PGIS. The 2015 sub-ice shelf temperature maxima exceed the 2002 value by $0.15^{\circ} \mathrm{C}$ (Fig. 3a).

The summertime temperature maxima described above provide snapshots of the subsurface ocean near PGIS from 2002 to 2015. These snapshots imply warming of the subsurface ocean over this time period. We quantify this warming by fitting a least squares linear regression $[\Theta(t)=a+b t]$ to the temperature maxima in Kennedy Channel, Hall Basin, Petermann Fjord, and the sub-ice shelf cavity. After fitting the linear regression to 43 data points that span 13 years, we find a $0.015^{\circ} \pm 0.013^{\circ} \mathrm{Cyr}^{-1}$ warming trend for the $2002-15$ period. This trend indicates subsurface warming near PGIS up to 2015 in summer. We next quantify the small bias due to seasonal variability.

We examine temperature and density time series data from an SBE 37-SM CT sensor moored beneath PGIS at 450-m depth, $13 \mathrm{~km}$ seaward of the glacier's grounding line (Figs. 4a,b). We estimate the linear trend along with the seasonal cycle $\left(w=2 \pi \mathrm{yr}^{-1}\right)$ by fitting a least squares regression to the data:

$$
\Theta(t)=a+b t+c \cos (w t)+d \sin (w t) .
$$

The temperature regression line trends upward from August to December 2015, but then levels off from December 2015 to April 2016, before once again sloping upward from April to August 2016 (Figs. 4a, b). These variations illustrate the seasonal effect on subsurface ocean warming below PGIS. However, the seasonal effect $\left(c^{2}+d^{2}\right)^{1 / 2}=0.004^{\circ} \pm 0.006^{\circ} \mathrm{C}$ is much smaller than the linear sub-ice shelf warming trend $b=0.025^{\circ} \pm 0.013^{\circ} \mathrm{Cyr}^{-1}$. The associated linear

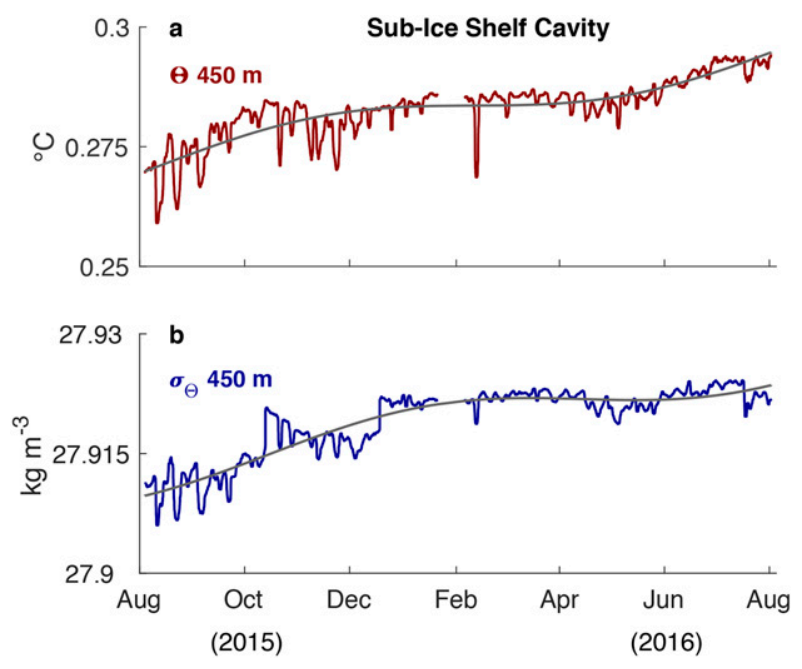

FIG. 4. The 2015-16 (a) Conservative Temperature and (b) potential density anomaly time series from the sub-ice shelf cavity. Data come from an instrument moored at 450-m depth, $13 \mathrm{~km}$ seaward of the grounding line. Gray lines represent least squares regression fit to the data that includes sinusoidal oscillations with a 1-yr period.

density trend $b=0.014 \pm 0.009 \mathrm{~kg} \mathrm{~m}^{-3} \mathrm{yr}^{-1}$ also overshadows the seasonal variability $\left(c^{2}+d^{2}\right)^{1 / 2}=0.003$ $\pm 0.004 \mathrm{~kg} \mathrm{~m}^{-3}$. Uncertainty represents $95 \%$ confidence intervals and derives from a 1- and 1.5-month decorrelation time scale that yields 7 and 4 degrees of freedom for the temperature and density data, respectively. The appendix provides details on error estimation (Fofonoff and Bryden 1975).

The sub-ice shelf warming trend agrees with the CTD-based warming trend within $95 \%$ confidence limits. It is also close to the $0.023^{\circ} \pm 0.015^{\circ} \mathrm{C} \mathrm{yr}^{-1}$ warming trend calculated by Münchow et al. (2011) using 6 years of hourly bottom temperature measurements between 2003 and 2009 in Kennedy Channel. When viewed together, these three independent warming trends provide consistent evidence that the subsurface ocean warmed near PGIS from 2002 to 2016.

We further investigate water column changes near PGIS by comparing 2012 and 2015 CTD profiles from the same along-fjord transect that extended from the ice shelf's terminus through Petermann Fjord and into Hall Basin. We interpolate these data onto a regular grid to quantify temperature and density differences between 2012 and 2015 (Figs. 5a,b). In Fig. 5, we separate the upper $100-300 \mathrm{~m}$ of the water column from the lower $300-600 \mathrm{~m}$ to isolate AW-sourced changes that affect the thick portion of PGIS from more variable signals higher in the water column. We neglect surface waters above $100 \mathrm{~m}$, because they relate to 

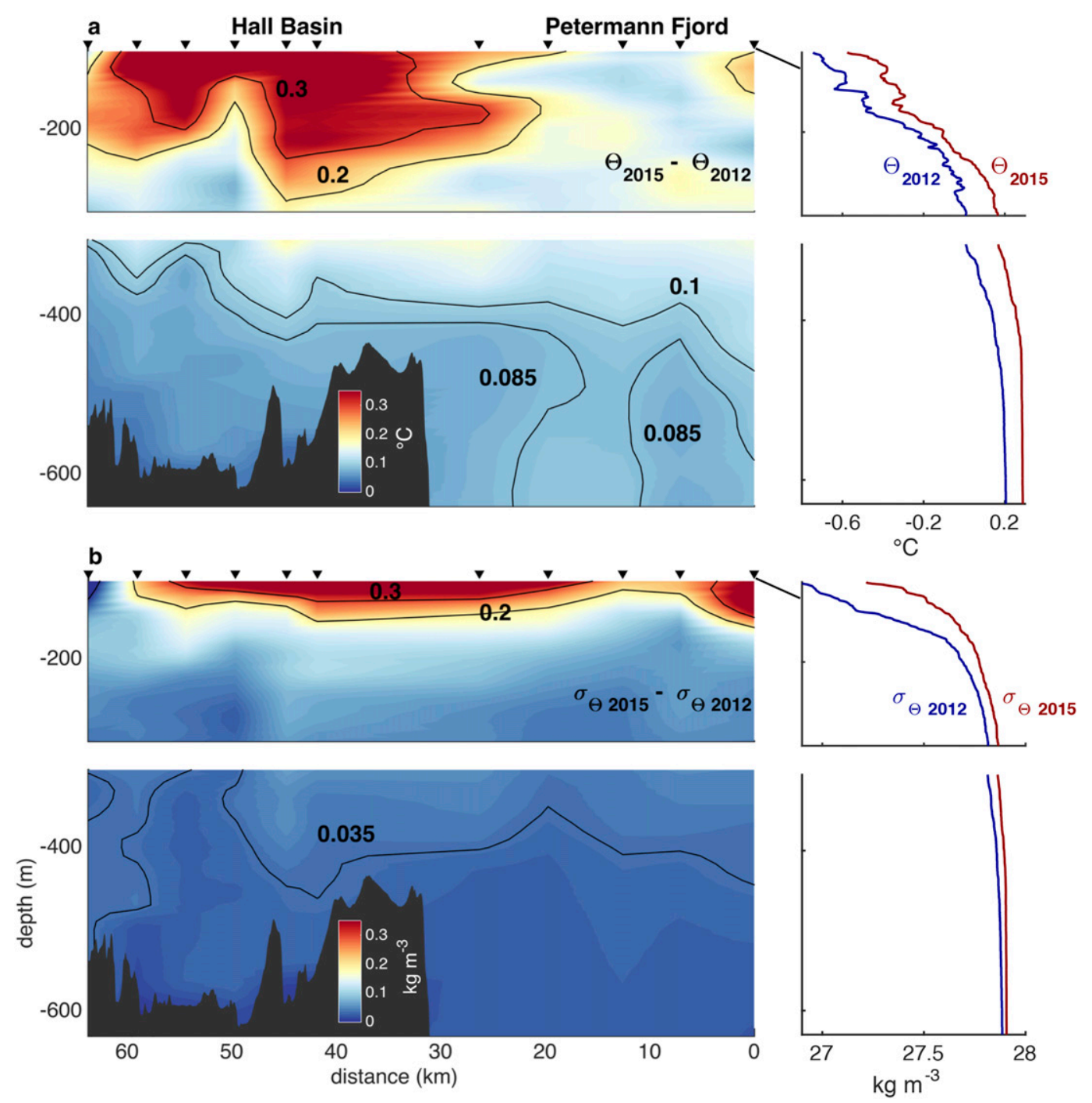

FIG. 5. (left) (a) Temperature and (b) density differences between 2012 and 2015 hydrographic transects from the PGIS terminus to Hall Basin from right to left across the panels. (right) The depth profiles of the associated property from the stations closest to the PGIS terminus.

local atmospheric forcing and do not extend below the $\geq 100$-m-thick ice shelf.

The 2015 temperatures exceed those in 2012 everywhere along the transect. Similarly, the 2015 densities surpass those in 2012 and reveal that these warmer waters are saltier. In the deep ocean, temperature and density increased by $0.1^{\circ} \mathrm{C}$ and $0.035 \mathrm{~kg} \mathrm{~m}^{-3}$, respectively, between 300 and $350 \mathrm{~m}$. Below this depth, ocean temperature increased by $0.085^{\circ} \mathrm{C}$ between transects with some variability in Petermann Fjord. While these differences closely follow the temperature maxima increase $\left(0.08^{\circ} \mathrm{C}\right)$ between 2012 and 2015, we observe stronger differences higher in the water column. Between 100 and $300 \mathrm{~m}$, we observe a $\geq 0.2^{\circ} \mathrm{C}$ warmer region in 2015 than in 2012 (Fig. 5a). This warming permeates Hall Basin and Petermann Fjord to within $15 \mathrm{~km}$ of the PGIS terminus. It also corresponds with $\mathrm{a} \geq 0.2 \mathrm{~kg} \mathrm{~m}^{-3}$ density increase, which implies a raised pycnocline and a less stratified 2015 water column below $100 \mathrm{~m}$ relative to 2012 (Fig. 5b).

\section{c. Stronger ocean circulation in Petermann Fjord}

Ocean warming near a glacier can accelerate submarine melting, release more freshwater into the nearby ocean, and drive stronger circulation (Jacobs et al. 2011). When the width of the fjord exceeds the internal deformation radius, Earth's rotation causes this circulation to vary across the fjord (Gill 1982). As this is the case in Petermann Fjord, we use the thermal wind relation to estimate geostrophic circulation 


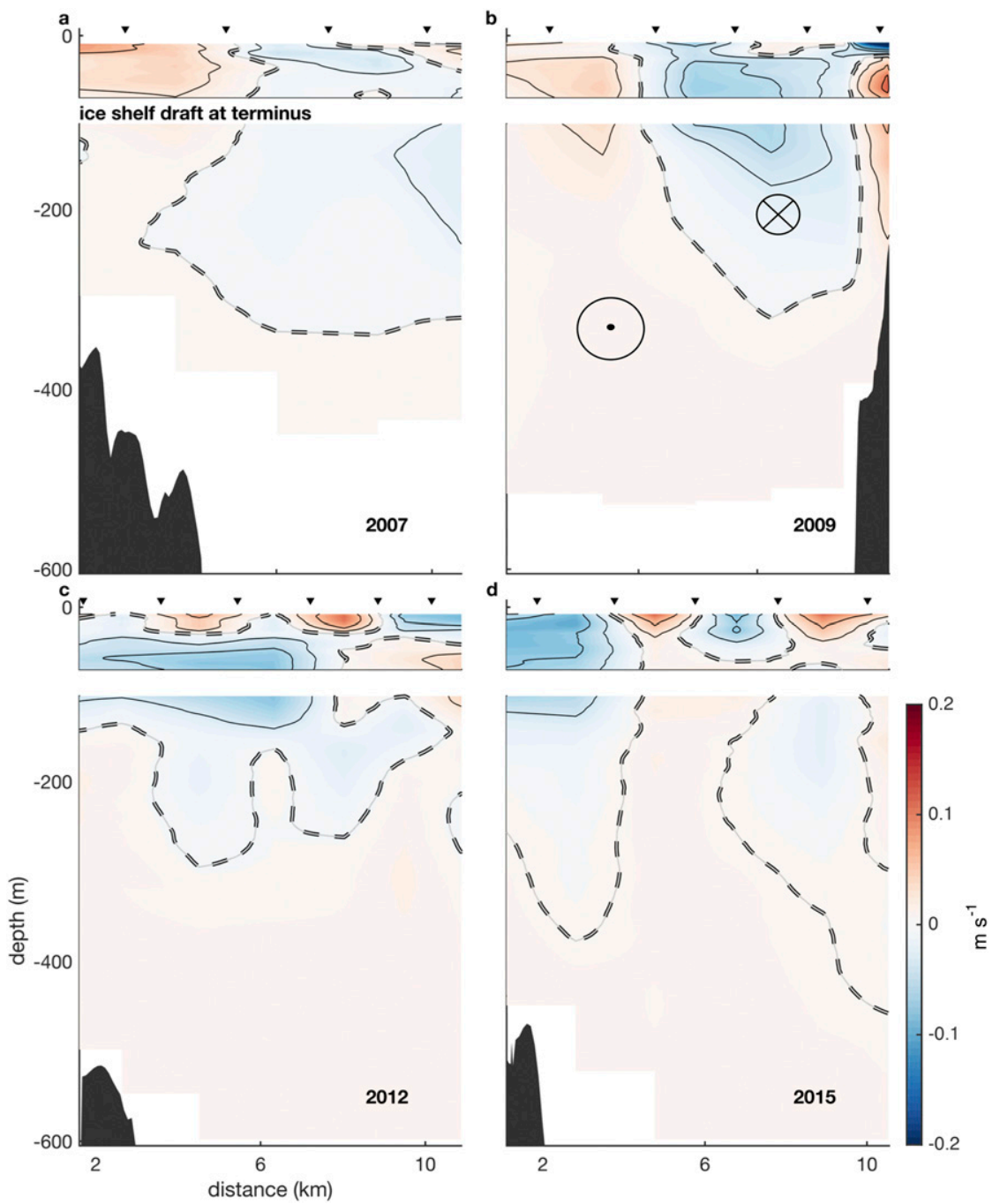

FIG. 6. Geostrophic velocities at the PGIS terminus for (a) 2007, (b) 2009, (c) 2012, and (d) 2015 sections. View is out of the fjord toward Canada. Velocities are positive when directed into the fjord. Velocities are contoured at a $0.03 \mathrm{~m} \mathrm{~s}^{-1}$ interval with the dashed contour line representing $0.00 \mathrm{~m} \mathrm{~s}^{-1}$. The upper $100 \mathrm{~m}$ of each plot are neglected in later heat flux estimates.

from baroclinic density gradients across hydrographic sections:

$$
\frac{\delta v_{g}}{\delta z}=\frac{-g}{\rho_{0} f} \frac{\delta \rho}{\delta x}
$$

where $f=1.4 \times 10^{-4} \mathrm{~s}^{-1}$ is the Coriolis parameter, $g=-9.8 \mathrm{~m} \mathrm{~s}^{-2}$ is the gravitational acceleration, and $\rho_{0}$ is the mean density from each hydrographic section. We compute the along-fjord component $v_{g}$ of the velocity by integrating from a $600-\mathrm{m}$ (glacier's grounding depth) assumed level of no flow. We then apply a constant barotropic flow to ensure geostrophic mass balance, that is, zero net flow (Montgomery 1974; Johnson et al. 2011). Figure 6 displays the geostrophic circulation at the PGIS terminus from 2007, 2009, 2012 , and 2015 summer hydrographic sections. The view is directed out of the fjord toward Canada, so distance is from the southwest corner of the fjord, and a positive flow moves water into the fjord. Velocity uncertainties depend on associated sensor uncertainties and are of order $0.03 \mathrm{~m} \mathrm{~s}^{-1}$.

Geostrophic ocean circulation at the PGIS terminus is weak in 2007: velocities hover around $0.00 \mathrm{~m} \mathrm{~s}^{-1}$, except for some weak outflow $\left(v_{g}=0.02 \mathrm{~m} \mathrm{~s}^{-1}\right)$ from the sub-ice shelf cavity on the northeast side of the fjord (Fig. 6a). The major compensating inflow hugs the southwest side of the fjord down to $~ 300$-m depth. In 2009, we estimate stronger geostrophic circulation with increased outflow ( $\max v_{g}=0.20 \mathrm{~m} \mathrm{~s}^{-1}$ ) in the middle 
and upper water column on the northeast side of the fjord (Fig. 6b). The opposing inflow occupies the deep ocean on the southwest side of the fjord. While this inflow is broad and weak $\left(v_{g}=\sim 0.003 \mathrm{~m} \mathrm{~s}^{-1}\right)$, it resides deep enough in the water column to penetrate the subice shelf cavity. In 2012 and 2015, we estimate similarly strong flow away from PGIS. While multiple flow reversals characterize the upper water column during both years, we observe the strongest outflow on the southwest side of the fjord. This differs from the 2007 and 2009 sections, where we observe the strongest outflow on the northeast side of the fjord. By altering the ice shelf's morphology and moving its terminus farther into Petermann Fjord, the 2010 and 2012 calving events could have relocated the maximum outflow to locations where reported channels line the underside of the ice shelf (Rignot and Steffen 2008). Below this, we estimate a broad inflow of $\sim 0.01 \mathrm{~m} \mathrm{~s}^{-1}$ in 2012 and 2015 (Figs. 6c,d). This inflow is important, because it transports warming AW beneath PGIS where it contributes to submarine melting.

\section{d. Sub-ice shelf measurements}

Figure $7 \mathrm{~b}$ indicates the three locations where we collected ocean CTD profiles via access holes drilled in the central channel of PGIS 3, 13 , and $26 \mathrm{~km}$ from the grounding line. Airborne radar and laser altimeter surveys highlight $1-2-\mathrm{km}$-wide basal channels that penetrate $0.2 \mathrm{~km}$ into the ice shelf's underside (Fig. 7a). If the ice shelf is in hydrostatic balance, then surface expressions are about $1 / 10$ the basal feature's magnitude (Cuffey and Paterson 2010).

Figure 8 shows vertical profiles of Conservative Temperature and Absolute Salinity from these three locations with an inset that provides reference to the glacier surface. The deep ocean in each profile resembles Petermann Fjord seaward of the PGIS terminus with relatively warm and salty AW extending from $\sim 500 \mathrm{~m}$ to the seafloor (Fig. 8). The temperature is nearly uniform within this $\mathrm{AW}$, but warms slightly from $0.28^{\circ} \mathrm{C}$ at $\sim 500 \mathrm{~m}$ to $0.29^{\circ} \mathrm{C}$ within $20 \mathrm{~m}$ of the seafloor. The salinity also varies slightly with depth from 34.93 to $34.94 \mathrm{~g} \mathrm{~kg}^{-1}$. The minimal variation in salinity implies a nearly uniform density below $\sim 500 \mathrm{~m}$ in the sub-ice shelf cavity.

Colder and fresher seawater overlays this quasiuniform AW below PGIS (Fig. 8). In each profile, we observe the coldest and freshest water near the ice base. At 13 and $26 \mathrm{~km}$ from the grounding line, a strong pycnocline separates the upper $10 \mathrm{~m}$ of the water column from the ocean below. Beneath this pycnocline, we observe gradual changes in temperature and salinity down to the AW, beginning at $520 \mathrm{~m}$. Over this depth range,
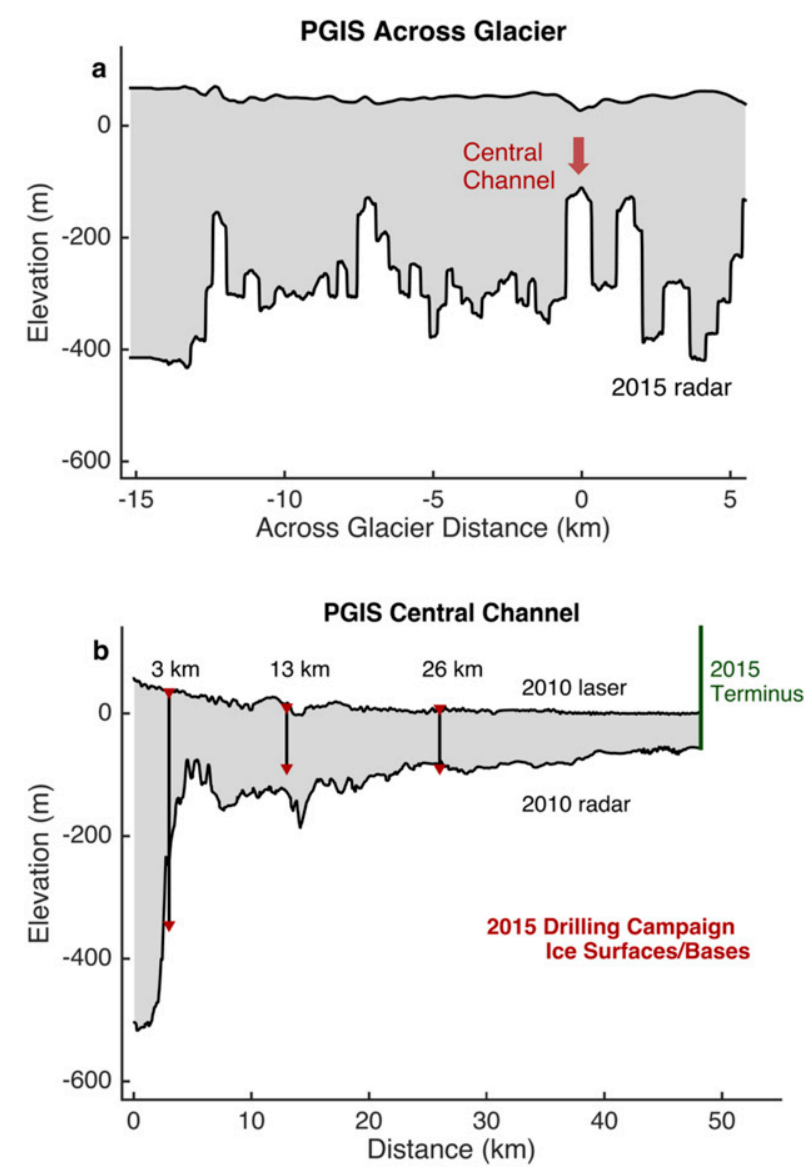

FIG. 7. Petermann Gletscher elevation profiles from airborne laser and radar surveys (Operation IceBridge). (a) The 5 May 2015 radar profile across glacier $\sim 15 \mathrm{~km}$ from the grounding line (see Fig. 1 for location). (b) The 24 Mar 2010 radar (bottom) and laser (surface) profile along glacier from the central PGIS channel up to the 2015 terminus. The 2015 ice drilling locations are indicated in (b). Red triangles denote ice shelf surface and basal elevations from the 2015 drilling campaign. Discrepancies between Operation IceBridge and ice drilling elevations likely arise from the 5-yr gap between the 2010 flight survey and the 2015 drilling campaign.

the 13- and 26-km profiles vary with respect to one another. While the $26-\mathrm{km}$ profile appears colder and fresher than the $13-\mathrm{km}$ profile from 130 to $300 \mathrm{~m}$, the $13-\mathrm{km}$ profile is colder and fresher from 300 to $520 \mathrm{~m}$. This progression toward colder and fresher water at these depths continues to the $3-\mathrm{km}$ profile. Between 345 and $420 \mathrm{~m}$, the $3-\mathrm{km}$ profile stands out as noticeably colder and fresher than the $13-$ and $26-\mathrm{km}$ profiles. Moreover, the $3-\mathrm{km}$ profile displays gradual changes in temperature and salinity from the ice base at $345 \mathrm{~m}$ down to the $\mathrm{AW}$ beginning at $450 \mathrm{~m}$. Figure 9 presents these data in $\Theta-S_{\mathrm{A}}$ space, where the deep temperature and salinity values lie on a straight line with a slope of $2.50^{\circ} \mathrm{C}\left(\mathrm{g} \mathrm{kg}^{-1}\right)^{-1}$. The slope of this line represents the 


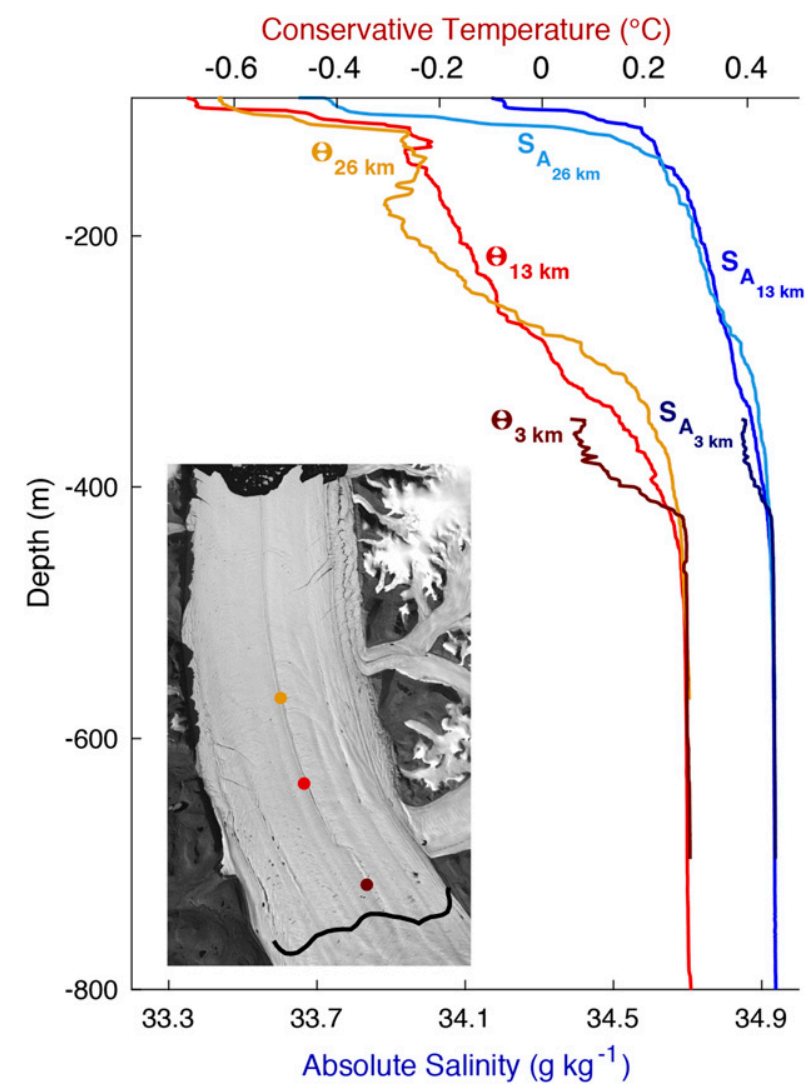

FIG. 8. Conservative Temperature and Absolute Salinity profiles from the central channel of PGIS at 3, 13, and $26 \mathrm{~km}$ from the grounding line. The inset displays these profile locations on Landsat-8 imagery of Petermann Gletscher.

mixing of AW and glacial meltwater. This meltwater releases into the ocean when AW melts fresh glacial ice along the base of PGIS (Gade 1979). The submarine melting of ice takes the latent heat from the ocean to convert ice to water at a fixed temperature. This latent heat loss leaves a cooling signal in the ambient ocean that we can track using Eq. (3) (Wåhlin et al. 2010):

$$
\Theta_{\text {gade }}\left(S_{\mathrm{A}}\right)=\Theta_{\mathrm{AW}}+\frac{L_{f}}{c_{p}}\left(1-\frac{S_{\mathrm{A}_{\mathrm{AW}}}}{S_{\mathrm{A}}}\right),
$$

where $\Theta_{\text {gade }}$ represents a predicted Conservative Temperature that depends on the Absolute Salinity $S_{\mathrm{A}}$ of water containing glacial meltwater and $\mathrm{AW}$. In this equation, $\mathrm{AW}\left(\Theta_{\mathrm{AW}}=0.28^{\circ} \mathrm{C}\right.$ and $\left.S_{\mathrm{A}_{\mathrm{AW}}}=34.93 \mathrm{~g} \mathrm{~kg}^{-1}\right)$ melts PGIS. The latent heat of fusion is $\mathrm{L}_{f}=334000 \mathrm{~J} \mathrm{~kg}^{-1}$, and the specific heat of seawater with salinity $S_{\mathrm{A}_{\mathrm{AW}}}$ is $c_{p}=3986 \mathrm{~J} \mathrm{~kg}^{-1}{ }^{\circ} \mathrm{C}^{-1}$.

A detailed examination of the $\Theta-S_{\mathrm{A}}$ diagram reveals that the CTD profiles taken below PGIS fit Eq. (3) between $\sigma_{\Theta}=27.90$ and $\sigma_{\Theta}=27.75 \mathrm{~kg} \mathrm{~m}^{-3}$ but then diverge at lower densities (Fig. 9). At $3 \mathrm{~km}$ from the grounding line, the CTD profile fits the glacial melt mixing line from $450 \mathrm{~m}\left(\sigma_{\Theta}=27.90 \mathrm{~kg} \mathrm{~m}^{-3}\right)$ directly to the ice-ocean boundary at $345 \mathrm{~m}$. At 13 and $26 \mathrm{~km}$, the profiles fit this mixing line from $520 \mathrm{~m}\left(\sigma_{\Theta}=27.90 \mathrm{~kg} \mathrm{~m}^{-3}\right)$ to $230 \mathrm{~m}$ $\left(\sigma_{\Theta}=27.80 \mathrm{~kg} \mathrm{~m}^{-3}\right)$ and $175 \mathrm{~m}\left(\sigma_{\Theta}=27.75 \mathrm{~kg} \mathrm{~m}^{-3}\right)$, respectively. Both profiles then depart from the glacial melt mixing line, indicating mixture with at least one additional water mass. Straneo et al. (2012) scrutinized summertime CTD profiles collected near Greenland's largest outlet glaciers (including Petermann Gletscher) and discovered that freshwater runoff $\left(\Theta=0^{\circ} \mathrm{C}, S_{\mathrm{A}}=\right.$ $0 \mathrm{~g} \mathrm{~kg}^{-1}$ ) played a significant role in the near-glacier water column. For PGIS, freshwater runoff enters either the shallow ocean at its terminus via its prominent surface river (Macdonald et al. 2018) or the deep ocean at its grounding line in the form of subglacial discharge. Straneo et al. (2012) defined a runoff mixing line that contained a mixture of seawater, glacial meltwater, and freshwater runoff. This runoff mixing line intersected the glacial melt mixing line at the deepest (densest) point in $T-S$ space where the profile departed from the glacial melt mixing line. They hence labeled this departure the runoff point, because profile data then veered from the glacial melt mixing line toward the runoff mixing line.

In Fig. 9, we establish separate runoff points for the 13- and 26-km profiles, because each departs from the glacial melt mixing line at a different location in $\Theta-S_{\mathrm{A}}$ space. We observe this departure at $-0.12^{\circ} \mathrm{C}$ and $34.77 \mathrm{~g} \mathrm{~kg}^{-1}$ $(230 \mathrm{~m})$ for the $13-\mathrm{km}$ profile and at $-0.30^{\circ} \mathrm{C}$ and $34.69 \mathrm{~g} \mathrm{~kg}^{-1}(175 \mathrm{~m})$ for the $26-\mathrm{km}$ profile (Fig. 9 inset). Above its respective runoff point, each profile then contains a mixture of AW, glacial meltwater, and freshwater runoff. We posit that this runoff takes the form of subglacial discharge at the grounding line that then mixes with $\mathrm{AW}$ and strengthens the meltwater-rich plume beneath the ice shelf, thus driving enhanced melting along the base of PGIS (Jenkins 2011). The buoyancy of the freshwater runoff and glacial meltwater carries this plume upward along the ice base. Upwelling of this plume brings glacially cooled and freshened AW upward in the water column, effectively freshening the ocean above the runoff point more than cooling it (Straneo et al. 2012). This creates an upward kink in $\Theta-S_{\mathrm{A}}$ space, which we observe at $-0.20^{\circ} \mathrm{C}$ and $34.60 \mathrm{~g} \mathrm{~kg}^{-1}$ $(130 \mathrm{~m})$ in both the 13- and 26-km profiles (Fig. 9 inset). Above $130 \mathrm{~m}$, the water cools due to interaction with the ice base, but remains warm when compared with the local freezing point of seawater (Hansen 1904; Fujino et al. 1974). We measure water that is $2^{\circ}, 1.2^{\circ}$, and $1.2^{\circ} \mathrm{C}$ above the local freezing point near the ice-ocean boundary at 3,13 , and $26 \mathrm{~km}$ from the grounding line, respectively. 


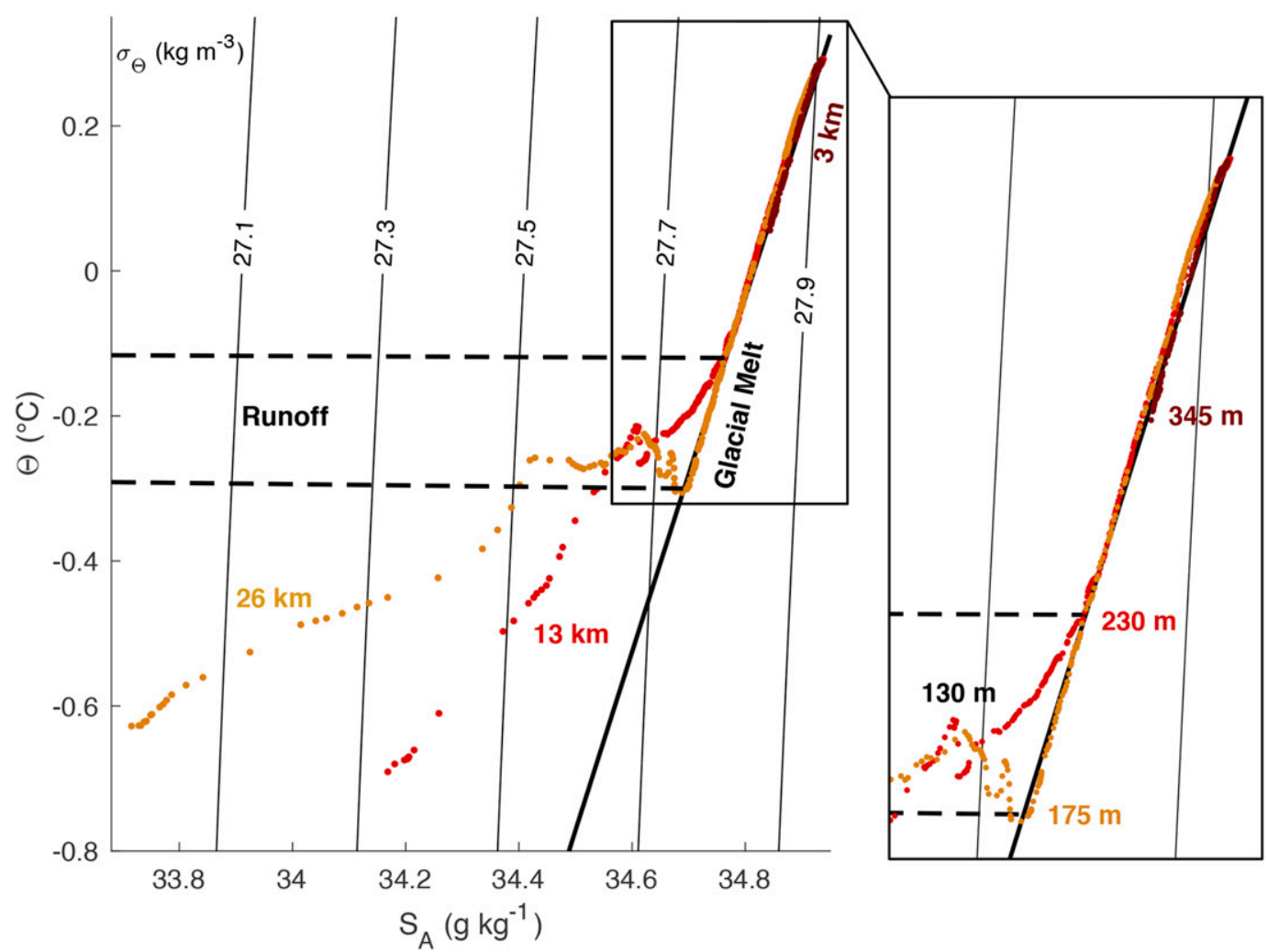

FIG. 9. Conservative Temperature vs Absolute Salinity diagram displaying the entire sampled water column below PGIS at 3,13, and $26 \mathrm{~km}$ from the grounding line. The enlarged inset shows the mixing line associated with submarine melting by AW. Color-coded depths indicate the respective profile's runoff point, and the 130-m label marks the $\Theta-S_{\mathrm{A}}$ signature of upwelling glacially modified AW.

\section{e. Geostrophic heat and freshwater fluxes}

Warm ocean waters beneath PGIS and a strong circulation at its terminus provide the context for rapid submarine melting. Johnson et al. (2011) created a steadystate model to estimate the ocean-forced melting of PGIS in 2009. In this model, they considered an ice shelf that was $16600 \mathrm{~m}$ wide, thinned from 600 to $50 \mathrm{~m}$ over its $70000-\mathrm{m}$ length, and flowed seaward at $1130 \mathrm{~m} \mathrm{yr}^{-1}$. By dividing the ice shelf's volume loss between the grounding line and terminus by the time elapsed, they calculated a net horizontal freshwater flux $F$ of $0.33 \mathrm{mSv}(1 \mathrm{mSv}=$ $10^{3} \mathrm{~m}^{3} \mathrm{~s}^{-1}$ ) out of the fjord. Attributing all of this to submarine melting, they calculated the required horizontal ocean heat flux $\left(Q=1.1 \times 10^{11} \mathrm{~W}\right)$ below the ice to force this melting:

$$
Q=\rho_{i} F\left(L_{f}+c_{i} \Delta \Theta\right)
$$

where $\rho_{i}=917 \mathrm{~kg} \mathrm{~m}^{-3}$ is the density of ice, $L_{f}=$ $334000 \mathrm{~J} \mathrm{~kg}^{-1}$ is the latent heat of fusion, $c_{i}=$ $2050 \mathrm{~J} \mathrm{~kg}^{-1{ }^{\circ}} \mathrm{C}^{-1}$ is the specific heat of ice, and $\Delta \Theta$ is the temperature difference between the in situ freezing point of seawater $\left(-2.11^{\circ} \mathrm{C}\right)$ and the ice $\left(-20^{\circ} \mathrm{C}\right)$. Dividing $Q$ by the ice shelf's area, Johnson et al. (2011) estimated an average vertical heat flux into the PGIS base of $97 \mathrm{~W} \mathrm{~m}^{-2}$.

Heuzé et al. (2017) repeated this procedure for PGIS in 2015, after the 2010 and 2012 calving events shortened it. Their model ice shelf retained the same $16600-\mathrm{m}$ width, but thinned from 600 to $200 \mathrm{~m}$ over its $48000-\mathrm{m}$ length and flowed seaward at $1250 \mathrm{~m} \mathrm{yr}^{-1}$. They estimated that the steady-state melting of PGIS in 2015 discharged $0.26 \mathrm{mSv}$ of freshwater away from the glacier. This melting required a horizontal heat flux beneath the ice shelf of $0.9 \times 10^{11} \mathrm{~W}$ and a vertical heat flux into its ice base of $111 \mathrm{~W} \mathrm{~m}^{-2}$.

Motivated by their values, Johnson et al. (2011) used geostrophic velocities from the 2009 hydrographic section taken at the PGIS terminus to estimate the net horizontal heat flux near the ice shelf. Likewise, Heuzé et al. (2017) used a 2015 hydrographic section taken across the Petermann Fjord sill to estimate the net geostrophic heat flux. We take a similar approach by estimating the net horizontal geostrophic heat flux from hydrographic sections taken at the PGIS terminus in 2007, 2009, 2012, and 2015. However, we limit our depth 
TABLE 2. Geostrophic heat $Q_{g}$ and freshwater $F_{g}$ fluxes. Note that area is the wet sectional area below the ice shelf base at its terminus that is resolved by hydrographic data. Barotropic constants come from geostrophic velocity estimates, and $S_{\mathrm{A}_{\mathrm{AW}}}$ values are chosen AW salinities for each year.

\begin{tabular}{|c|c|c|c|c|c|c|}
\hline & Year & $\begin{array}{c}\text { Area } \\
\left(\mathrm{km}^{2}\right)\end{array}$ & $\begin{array}{l}\text { Barotropic constant } \\
\qquad\left(\mathrm{m} \mathrm{s}^{-1}\right)\end{array}$ & $\begin{array}{c}Q_{g} \\
\left(1 \times 10^{11} \mathrm{~W}\right)\end{array}$ & $\begin{array}{c}S_{\mathrm{A}_{\mathrm{AW}}} \\
\left(\mathrm{g} \mathrm{kg}^{-1}\right)\end{array}$ & $\begin{array}{c}F_{g} \\
(\mathrm{mSv})\end{array}$ \\
\hline \multicolumn{7}{|l|}{ PGIS terminus: } \\
\hline & 2007 & 4.3 & 0.002 & $-0.5 \pm 0.1$ & 34.90 & $0.7 \pm 0.2$ \\
\hline & 2009 & 6.2 & 0.008 & $1.5 \pm 0.2$ & 34.93 & $1.9 \pm 0.2$ \\
\hline & 2012 & 5.6 & 0.009 & $1.7 \pm 0.2$ & 34.93 & $2.2 \pm 0.2$ \\
\hline & 2015 & 5.3 & 0.009 & $1.8 \pm 0.1$ & 34.94 & $2.5 \pm 0.1$ \\
\hline
\end{tabular}

range to between 100 and $600 \mathrm{~m}$, because while the 2012 and 2015 hydrographic data reached all the way to the bottom of the 1100-m-deep Petermann Fjord, the 2007 and 2009 data did not. By limiting our depth range, we consider interannual ocean heat flux changes over similar areas. We compare the 2007 and 2009 heat flux estimates with the steady-state melt values of Johnson et al. (2011), because the ice shelf structure varied little between those years. Likewise, we compare our 2012 and 2015 estimates with the steady-state melt values of Heuzé et al. (2017), because PGIS had already calved at the time of the 2012 hydrographic section. We estimate the net horizontal geostrophic heat flux $Q_{g}$; that is:

$$
Q_{g}=\int_{A} \rho_{0} c_{p}\left(\Theta-\Theta_{f}\right) v_{g} \delta A,
$$

where $\rho_{0}=1027 \mathrm{~kg} \mathrm{~m}^{-3}$ is a reference density, and $\Theta-\Theta_{f}$ is the Conservative Temperature above freezing. Table 2 provides our geostrophic heat flux estimates for each year, along with compensating barotropic constants and hydrographic section areas.

In 2007, we estimate a weak outflow of heat $\left[Q_{g}=(-0.5 \pm\right.$ $\left.0.1) \times 10^{11} \mathrm{~W}\right]$ from beneath PGIS. This changes in 2009 , when we estimate a net inflow of heat $\left[Q_{g}=(1.5 \pm\right.$ $\left.0.2) \times 10^{11} \mathrm{~W}\right]$ into the sub-ice shelf cavity that exceeds the $1.1 \times 10^{11} \mathrm{~W}$ required for steady-state melting of PGIS. Similarly, in $2012\left[Q_{g}=(1.7 \pm 0.2) \times 10^{11} \mathrm{~W}\right]$ and 2015 $\left[Q_{g}=(1.8 \pm 0.1) \times 10^{11} \mathrm{~W}\right]$, we estimate net geostrophic heat fluxes below PGIS that are twice the $0.9 \times 10^{11} \mathrm{~W}$ required to drive steady-state melting. When we integrate the 2012 and 2015 sections completely to the seafloor, we find that $Q_{g}$ increases to $(2.6 \pm 0.4) \times 10^{11}$ $\mathrm{W}$ and $(2.9 \pm 0.2) \times 10^{11} \mathrm{~W}$, respectively.

Substantial heat flux into the sub-ice shelf cavity can drive rapid submarine melting of PGIS, which then exports more freshwater into Petermann Fjord. We estimate the horizontal geostrophic freshwater flux $F_{g}$ away from PGIS between 20- and 600-m depth as

$$
F_{g}=\int_{A}\left(\frac{S_{\mathrm{A}_{\mathrm{AW}}}}{S_{\mathrm{A}}}-1\right) v_{g} \delta A,
$$

where $S_{\mathrm{A}_{\mathrm{AW}}}$ is the Absolute Salinity of the AW that melts the base of PGIS near the grounding line. Table 2 lists the main results: freshwater flux estimates away from PGIS are $0.7 \pm 0.2,1.9 \pm 0.2,2.2 \pm 0.2$, and $2.5 \pm$ $0.1 \mathrm{mSv}$ in 2007, 2009, 2012, and 2015, respectively. Note that these estimates represent all freshwater present in the water column at the PGIS terminus, which includes glacial meltwater produced by submarine melting, as well as surface and subglacial runoff sources.

\section{Discussion}

Münchow et al. (2011) analyzed Nares Strait mooring data and found that the subsurface ocean adjacent to Petermann Gletscher warmed from 2003 to 2009 due to AW inflow from the Lincoln Sea. We confirm that this warming continued to 2015 by comparing temperature maxima from CTD profiles collected in Nares Strait, Petermann Fjord, and the ocean cavity beneath PGIS between 2002 and 2015. Furthermore, we diagnose similar warming beneath PGIS from 2015-16 mooring data and conclude that AW from the Lincoln Sea enters Nares Strait and arrives beneath PGIS approximately 1 or 2 years later.

Maximum submarine melting occurs within $10 \mathrm{~km}$ of the PGIS grounding line, which makes it sensitive to the temperature of the underlying AW (Rignot and Steffen 2008). In 2015, we identify a $\sim 200$-m-thick layer of AW extending from $\sim 500 \mathrm{~m}$ to the seafloor within this region of maximum melting. This $\mathrm{AW}$ exceeds the local freezing point by more than $2.5^{\circ} \mathrm{C}$ and thus contains ample heat to drive strong submarine melting along the PGIS base. Higher in the water column, the now glacially modified AW remains $1^{\circ} \mathrm{C}$ above freezing and thus contains sufficient heat to also melt the outer ice shelf.

This ocean warming coincides with a stronger geostrophic circulation near Petermann Gletscher. While our geostrophic velocity fields do not resolve current variability at tidal to seasonal time scales, they do provide useful estimates of ocean circulation during multiple summers. Horizontal geostrophic heat flux estimates below PGIS in 2009, 2012, and 2015 are higher than those required to force steady-state melting of the ice 
shelf (Johnson et al. 2011; Heuzé et al. 2017). They hence reveal that additional heat is available beneath PGIS. Similarly, our 2007, 2009, 2012, and 2015 freshwater flux estimates exceed the steady-state melt freshwater flux by 2-10 times (Johnson et al. 2011; Heuzé et al. 2017). While these estimates appear high, they are consistent with modeling results from Cai et al. (2017), who attributed much of this freshwater to subglacial discharge. We identify the influence of freshwater runoff from subglacial discharge in two out of the three sub-ice shelf CTD profiles. The absence of this signature in the profile nearest the grounding line could be due to the time of its collection, which was late in the summer season when subglacial discharge diminishes.

Freshwater flux away from PGIS increased by $0.6 \pm$ $0.3 \mathrm{mSv}$ between the 2009 and 2015 sections. Given the warmer AW in 2015 and its larger inflow velocities, the statistically similar 2009, 2012, and 2015 net heat fluxes suggest stronger submarine melting in 2015. This stronger 2015 melting is consistent with the larger observed 2015 freshwater flux.

We posit that this stronger submarine melting drives the "non steady state" $3-5 \mathrm{~m} \mathrm{yr}^{-1}$ net thinning of PGIS reported by Münchow et al. (2014). When we apply this thinning to the 2009 Johnson et al. (2011) model ice shelf, it contributes an additional $0.1-0.2 \mathrm{mSv}$ to the freshwater flux away from the glacier over the entire year. However, Jenkins (2011) revealed that subglacial discharge strengthens the under-ice buoyant melt plume and enhances submarine melting. Cai et al. (2017) likewise found that subglacial discharge doubled PGIS melt rates within $15 \mathrm{~km}$ of the grounding line. It is reasonable then to suggest that much of the non-steady-state thinning of the ice shelf occurs during the warm summer months. If we limit our period for ice shelf thinning to June-August, then our 2009 freshwater flux increases to $0.4-0.7 \mathrm{mSv}$ for these 3 months. When we apply the 3-5 $\mathrm{m} \mathrm{yr}^{-1}$ net thinning to the 2015 Heuzé et al. (2017) model ice shelf, it contributes $0.3-0.5 \mathrm{mSv}$ to the flux from June to August. When we factor in the Cai et al. (2017) August subglacial discharge estimate of $0.7 \mathrm{mSv}$, our expected summertime freshwater flux totals $1.4-1.7 \mathrm{mSv}$ in 2009 and $1.3-1.5 \mathrm{mSv}$ in 2012 and 2015. While the 2009 expected and estimated freshwater fluxes agree within their confidence limits, the 2012 and 2015 estimates exceed the expected freshwater flux by $0.5-1.1 \mathrm{mSv}$.

\section{Conclusions}

Warm Atlantic water (AW) passes over a 290-m sill from the Lincoln Sea into Nares Strait, where its high density causes it to sink. Continued inflow of this AW fills Nares Strait's Robeson Channel until the AW spills into Hall Basin, then over a 440-m sill into Petermann Fjord and below the ice shelf. We observe a $0.2^{\circ} \mathrm{C}$ warming of the AW surrounding PGIS from 2002 to 2016 after warmer AW arrived in the Lincoln Sea (de Steur et al. 2013). Consistent with this warming, we describe a stronger ocean circulation near PGIS that more readily transports the warmer AW into the sub-ice shelf cavity. Net horizontal heat fluxes beneath the ice shelf exceed the requirement for steady-state melting. Larger freshwater fluxes away from PGIS imply stronger submarine melting. Enhanced by summer subglacial discharge, warmer AW drives stronger submarine melting of PGIS, which, we argue, causes "non steady state" thinning of the ice shelf. Münchow et al. (2014) observed such thinning in the years leading up to the 2010 and 2012 PGIS calving events that reduced the ice shelf's length by one-third. Satellite observations expose two converging rifts on the glacier's surface $\sim 10 \mathrm{~km}$ from its terminus. PGIS will likely calve again when the rifts meet, reducing it to one-half of its 2010 precalving length. With the recent collapse of Jakobshavn Isbrae and Zachariae Isstrom's ice shelves in response to ocean warming, we speculate that the same process is occurring at Petermann Gletscher. If this is indeed the case, then the retreating ice shelf of Petermann Gletscher will contain less mass to buttress the grounded glacier flowing into it. This mass reduction will in turn produce increased ice velocities and drive heightened mass loss from the Greenland Ice Sheet.

Acknowledgments. We thank the editor and three anonymous reviewers for their insightful comments on the manuscript. Both the National Science Foundation (NSF) and National Aeronautics and Space Administration (NASA) supported this work over many years. We are grateful to crew and staff aboard the Canadian Coast Guard ship Henry Larsen in 2012 and the Swedish Ice Breaker Oden in 2015. Humfrey Melling of the Institute of Ocean Sciences in Canada and Alan Mix of Oregon State University generously shared time and resources at sea in 2012 and 2015, respectively. The 2015 bottom bathymetry data were kindly provided to us at sea in preliminary form by Martin Jakobsson of the University of Stockholm. Paul Anker and Mike Brian of the British Antarctic Survey provided critical support for hot water drilling and glacier traveling. The Ocean Weather Station was designed and built by David Huntley at the University of Delaware and funded by NASA Grant NNX15AL77G. AM was supported by a subcontract from Jet Propulsion Laboratory in 2015 and NSF Grants 102843 and 1604076 in 2012 and 2016, respectively. 


\section{APPENDIX}

\section{Confidence Intervals for Multiple Regression Coefficients}

We follow the methodology of Fofonoff and Bryden (1975) when computing confidence intervals for the multiple coefficients used in the sub-ice shelf regressions. Given temperature or density data $Y_{k} ; k=1,2, \ldots, K$, we fit a linear and sinusoidal least squares regression with coefficients $b_{i} ; i=1,2,3,4$

$$
\hat{Y}_{k}=b_{1}+b_{2} t_{k}+b_{3} \cos \left(w t_{k}\right)+b_{4} \sin \left(w t_{k}\right)
$$

to model data. Minimizing the sum of the squared residuals $\varepsilon_{k}^{2}=\left(Y_{k}-\hat{Y}_{k}\right)^{2}$,

$$
G_{K}=\sum_{k=1}^{K} \varepsilon_{k}^{2},
$$

with respect to the coefficients $b_{i}$ yields the linear equations:

$$
\sum_{j=1}^{4} R_{i j} b_{j}=Z_{i}, \quad i=1,2,3,4,
$$

where

$$
R_{i j}=\sum_{k=1}^{K} X_{i k} X_{j k}, \quad Z_{i}=\sum_{k=1}^{K} X_{i k} Y_{k}, \quad i=1,2,3,4,
$$

and

$X_{1 k}=1, \quad X_{2 k}=t_{k}, \quad X_{3 k}=\cos \left(w t_{k}\right), \quad X_{4 k}=\sin \left(w t_{k}\right)$.

We solve these equations by inverting $R_{i j}^{-1}=C_{i j}$ to find

$$
b_{i}=\sum_{j=1}^{4} C_{i j} Z_{j}=\sum_{j=1}^{4} \sum_{k=1}^{K} C_{i j} X_{j k} Y_{k}, \quad i=1,2,3,4 .
$$

Following Fofonoff and Bryden (1975), we assume that $Y_{k}$ is a random variable normally distributed about a mean $Y^{0}$ with variance $V(Y)=\sigma^{2}$. This ensures that the coefficients $b_{i}$ are also random variables with a variance $V\left(b_{i}\right)$ expressed as

$$
V\left(b_{i}\right)=\sum_{k=1}^{K}\left(\sum_{j=1}^{4} C_{i j} X_{j k}\right)^{2} V(Y)=C_{i i} \sigma^{2} .
$$

With the regression coefficients defined as random variables, we can solve for the variance $\sigma^{2}$ :

$$
\sigma^{2}=Y_{k}-Y^{0}=\hat{Y}_{k}-\hat{Y}^{0}+\varepsilon_{k},
$$

which has an unbiased expected value of

$$
\sigma^{2}=\frac{G_{K}}{N-4} .
$$

The degrees of freedom $N$ are

$$
N=\frac{T_{K}}{T_{D}}
$$

where $T_{K}$ is the record length, and $T_{D}$ is the decorrelation time scale, which represents the integral of the autocorrelation of the temperature or density data $Y_{k}$ from zero lag to the time of its first zero crossing (Poulain and Niiler 1989). Hence, we calculate $95 \%$ confidence intervals for each coefficient $b_{i}$ using a Student's $t$ distribution with $N-4$ degrees of freedom:

$$
\text { uncertainty }\left(b_{i}\right)= \pm t_{0.05} \sqrt{\sigma^{2} C_{i i}} .
$$

\section{REFERENCES}

Aagaard, K., 1989: A synthesis of the Arctic Ocean circulation. Rapp. P.-V. Reun. Cons. Int. Explor. Mer, 188, 11-22.

- L. Coachman, and E. Carmack, 1981: On the halocline of the Arctic Ocean. Deep-Sea Res., 28A, 529-545, https://doi.org/ 10.1016/0198-0149(81)90115-1.

Bindschadler, R., 2006: Hitting the ice sheets where it hurts. Science, 311, 1720-1721, https://doi.org/10.1126/science.1125226.

Cai, C., E. Rignot, D. Menemenlis, and Y. Nakayama, 2017: Observations and modeling of ocean-induced melt beneath Petermann Glacier Ice Shelf in northwestern Greenland. Geophys. Res. Lett., 44, 8396-8403, https://doi.org/10.1002/ 2017 GL073711.

Carmack, E. C., and Coauthors, 1997: Changes in temperature and tracer distributions within the Arctic Ocean: Results from the 1994 Arctic Ocean section. Deep-Sea Res. II, 44, 1487-1502, https://doi.org/10.1016/S0967-0645(97)00056-8.

Christoffersen, P., R. Mugford, K. Heywood, I. Joughin, J. Dowdeswell, J. Syvitski, A. Luckman, and T. Benham, 2011: Warming of waters in an East Greenland fjord prior to glacier retreat: Mechanisms and connection to large-scale atmospheric conditions. Cryosphere, 5, 701-714, https://doi.org/10.5194/tc-5-701-2011.

Cuffey, K. M., and W. S. B. Paterson, 2010: The Physics of Glaciers. 4th ed. Elsevier, 704 pp.

de Steur, L., and Coauthors, 2013: Hydrographic changes in the Lincoln Sea in the Arctic Ocean with focus on an upper ocean freshwater anomaly between 2007 and 2010. J. Geophys. Res. Oceans, 118, 4699-4715, https://doi.org/ 10.1002/jgrc.20341.

Dunbar, M., 1973: Ice regime and ice transport in Nares Strait. Arctic, 26, 282-291, https://doi.org/10.14430/arctic2927.

Enderlin, E. M., I. M. Howat, S. Jeong, M. J. Noh, J. H. Angelen, and M. R. van den Broeke, 2014: An improved mass budget for the Greenland Ice Sheet. Geophys. Res. Lett., 41, 866-872, https://doi.org/10.1002/2013GL059010. 
Farmer, D. M., and H. J. Freeland, 1983: The physical oceanography of fjords. Prog. Oceanogr., 12, 147-219, https://doi.org/ 10.1016/0079-6611(83)90004-6.

Fofonoff, N. P., and H. Bryden, 1975: Specific gravity and density of seawater at atmospheric pressure. J. Mar. Res., 33, 69-82.

Fujino, K., E. Lewis, and R. Perkin, 1974: The freezing point of seawater at pressures up to 100 bars. J. Geophys. Res., 79, 1792-1797, https://doi.org/10.1029/JC079i012p01792.

Gade, H. G., 1979: Melting of ice in sea water: A primitive model with application to the Antarctic ice shelf and icebergs. J. Phys. Oceanogr., 9, 189-198, https://doi.org/10.1175/15200485(1979)009<0189:MOIISW > 2.0.CO;2.

Gill, A. E., 1982: Atmosphere-Ocean Dynamics. International Geophysics Series, Vol. 30, Academic Press, 662 pp.

Gogineni, S., and Coauthors, 2001: Coherent radar ice thickness measurements over the Greenland Ice Sheet. J. Geophys. Res., 106, 33 761-33 772, https://doi.org/10.1029/2001JD900183.

Hansen, H. J., 1904: Experimental determination of the relation between the freezing point of sea-water and its specific gravity at $0^{\circ}$ C. Medd. Komm. Havunders. Ser. Hydrogr., 1 (2), 1-10.

Heuzé, C., A. Wåhlin, H. L. Johnson, and A. Münchow, 2017: Pathways of meltwater export from Petermann Glacier, Greenland. J. Phys. Oceanogr., 47, 405-418, https://doi.org/10.1175/JPO-D-16-0161.1.

Hogg, A. E., A. Shepherd, N. Gourmelen, and M. Engdahl, 2016: Grounding line migration from 1992 to 2011 on Petermann Glacier, north-west Greenland. J. Glaciol., 62, 1104-1114, https://doi.org/10.1017/jog.2016.83.

Holland, D. M., R. H. Thomas, B. de Young, M. H. Ribergaard, and B. Lyberth, 2008: Acceleration of Jakobshavn Isbrae triggered by warm subsurface ocean waters. Nat. Geosci., 1, 659-664, https://doi.org/10.1038/ngeo316.

Jacobs, S. S., A. Jenkins, C. F. Giulivi, and P. Dutrieux, 2011: Stronger ocean circulation and increased melting under Pine Island Glacier ice shelf. Nat. Geosci., 4, 519-523, https:// doi.org/10.1038/ngeo1188.

Jenkins, A., 2011: Convection-driven melting near the grounding lines of ice shelves and tidewater glaciers. J. Phys. Oceanogr., 41, 2279-2294, https://doi.org/10.1175/JPO-D-11-03.1.

Johnson, H., A. Münchow, K. Falkner, and H. Melling, 2011: Ocean circulation and properties in Petermann Fjord, Greenland. J. Geophys. Res., 116, C01003, https://doi.org/ 10.1029/2010JC006519.

Kanzow, T., U. Send, W. Zenk, A. D. Chave, and M. Rhein, 2006: Monitoring the integrated deep meridional flow in the tropical North Atlantic: Long-term performance of a geostrophic array. Deep-Sea Res. I, 53, 528-546, https://doi.org/10.1016/ j.dsr.2005.12.007.

Krabill, W., and Coauthors, 2002: Aircraft laser altimetry measurement of elevation changes of the Greenland Ice Sheet: Technique and accuracy assessment. J. Geodyn., 34, 357-376, https://doi.org/10.1016/S0264-3707(02)00040-6.

Kwok, R., 2005: Variability of Nares Strait ice flux. Geophys. Res. Lett., 32, L24502, https://doi.org/10.1029/2005GL024768.

Macdonald, G. J., A. F. Banwell, and D. R. MacAyeal, 2018: Seasonal evolution of supraglacial lakes on a floating ice tongue, Petermann Glacier, Greenland. Ann. Glaciol., 59, 56-65, https://doi.org/10.1017/aog.2018.9.

Makinson, K., and P. G. Anker, 2014: The BAS ice-shelf hot-water drill: Design, methods and tools. Ann. Glaciol., 55, 44-52, https://doi.org/10.3189/2014AoG68A030.

McDougall, T. J., and P. M. Barker, 2011: Getting started with TEOS-10 and the Gibbs Seawater (GSW) oceanographic toolbox. SCOR/IAPSO WG Rep., 28 pp.
McLaughlin, F., E. Carmack, R. Macdonald, A. J. Weaver, and J. Smith, 2002: The Canada Basin, 1989-1995: Upstream events and far-field effects of the Barents Sea. J. Geophys. Res., 107, 3082, https://doi.org/10.1029/2001JC000904.

Montgomery, R., 1974: Comments on "Seasonal variability of the Florida Current" by Niiler and Richardson. J. Mar. Res., 32, 533-535.

Mortensen, J., K. Lennert, J. Bendtsen, and S. Rysgaard, 2011: Heat sources for glacial melt in a sub-Arctic fjord (Godthåbsfjord) in contact with the Greenland Ice Sheet. J. Geophys. Res., 116, C01013, https://doi.org/10.1029/ 2010JC006528.

Mouginot, J., E. Rignot, B. Scheuchl, I. Fenty, A. Khazendar, M. Morlighem, A. Buzzi, and J. Paden, 2015: Fast retreat of Zachariæ Isstrøm, northeast Greenland. Science, 350, 13571361, https://doi.org/10.1126/science.aac7111.

Münchow, A., K. K. Falkner, H. Melling, B. Rabe, and H. L. Johnson, 2011: Ocean warming of Nares Strait bottom waters off northwest Greenland 2003-2009. Oceanography, 24 (3), 114-123, https://doi.org/10.5670/oceanog.2011.62.

_ L. Padman, and H. A. Fricker, 2014: Interannual changes of the floating ice shelf of Petermann Gletscher, North Greenland, from 2000 to 2012. J. Glaciol., 60, 489-499, https:// doi.org/10.3189/2014JoG13J135.

_- K. K. Falkner, and H. Melling, 2015: Baffin Island and West Greenland current systems in northern Baffin Bay. Prog. Oceanogr., 132, 305-317, https://doi.org/10.1016/ j.pocean.2014.04.001.

- L. Padman, P. Washam, and K. W. Nicholls, 2016: The ice shelf of Petermann Gletscher, North Greenland, and its connection to the Arctic and Atlantic Oceans. Oceanography, 29 (4), 84-95, https://doi.org/10.5670/oceanog.2016.101.

Nick, F. M., A. Vieli, M. L. Andersen, I. Joughin, A. Payne, T. L. Edwards, F. Pattyn, and R. S. van de Wal, 2013: Future sealevel rise from Greenland's main outlet glaciers in a warming climate. Nature, 497, 235-238, https://doi.org/ 10.1038/nature12068.

Pavlis, N. K., S. A. Holmes, S. C. Kenyon, and J. K. Factor, 2012: The development and evaluation of the Earth Gravitational Model 2008 (EGM2008). J. Geophys. Res., 117, B04406, https://doi.org/10.1029/2011JB008916.

Poulain, P.-M., and P. P. Niiler, 1989: Statistical analysis of the surface circulation in the California Current System using satellite-tracked drifters. J. Phys. Oceanogr., 19, 1588-1603, https://doi.org/10.1175/1520-0485(1989)019<1588: SAOTSC $>2.0 . \mathrm{CO} ; 2$.

Rignot, E., and P. Kanagaratnam, 2006: Changes in the velocity structure of the Greenland Ice Sheet. Science, 311, 986-990, https://doi.org/10.1126/science.1121381.

— , and K. Steffen, 2008: Channelized bottom melting and stability of floating ice shelves. Geophys. Res. Lett., 35, L02503, https://doi.org/10.1029/2007GL031765.

_, S. Gogineni, I. Joughin, and W. Krabill, 2001: Contribution to the glaciology of northern Greenland from satellite radar interferometry. J. Geophys. Res., 106, $34007-34019$, https:// doi.org/10.1029/2001JD900071.

— M. Koppes, and I. Velicogna, 2010: Rapid submarine melting of the calving faces of West Greenland glaciers. Nat. Geosci., 3, 187-191, https://doi.org/10.1038/ngeo765.

Rudels, B., E. Jones, L. Anderson, and G. Kattner, 1994: On the intermediate depth waters of the Arctic Ocean. The Polar Oceans and Their Role in Shaping the Global Environment, Geophys. Monogr., Vol. 85, Amer. Geophys. Union, 33-46. 
Ryan, P. A., and A. Münchow, 2017: Sea ice draft observations in Nares Strait from 2003 to 2012. J. Geophys. Res. Oceans, 122, 3057-3080, https://doi.org/10.1002/2016JC011966.

Sadler, H. E., 1976: Water, heat, and salt transports through Nares Strait, Ellesmere Island. J. Fish. Res. Board Can., 33, 22862295, https://doi.org/10.1139/f76-275.

Shroyer, E., L. Padman, R. Samelson, A. Münchow, and L. Stearns, 2017: Seasonal control of Petermann Gletscher ice-shelf melt by the ocean's response to sea-ice cover in Nares Strait. J. Glaciol., 63, 324-330, https://doi.org/10.1017/jog.2016.140.

Steele, M., J. Morison, W. Ermold, I. Rigor, M. Ortmeyer, and K. Shimada, 2004: Circulation of summer Pacific halocline water in the Arctic Ocean. J. Geophys. Res., 109, C02027, https://doi.org/10.1029/2003JC002009.

Straneo, F., and P. Heimbach, 2013: North Atlantic warming and the retreat of Greenland's outlet glaciers. Nature, 504, 36-43, https://doi.org/10.1038/nature12854.

- and C. Cenedese, 2015: The dynamics of Greenland's glacial fjords and their role in climate. Annu. Rev. Mar. Sci., 7, 89112, https://doi.org/10.1146/annurev-marine-010213-135133.
— G. S. Hamilton, D. A. Sutherland, L. A. Stearns, F. Davidson, M. O. Hammill, G. B. Stenson, and A. Rosing-Asvid, 2010: Rapid circulation of warm subtropical waters in a major glacial fjord in East Greenland. Nat. Geosci., 3, 182-186, https:// doi.org/10.1038/ngeo764.

- , R. G. Curry, D. A. Sutherland, G. S. Hamilton, C. Cenedese, K. Våge, and L. A. Stearns, 2011: Impact of fjord dynamics and glacial runoff on the circulation near Helheim Glacier. Nat. Geosci., 4, 322-327, https://doi.org/10.1038/ngeo1109.

- , and Coauthors, 2012: Characteristics of ocean waters reaching Greenland's glaciers. Ann. Glaciol., 53, 202-210, https:// doi.org/10.3189/2012AoG60A059.

van den Broeke, M., J. Bamber, J. Ettema, E. Rignot, E. Schrama, W. J. van de Berg, and B. Wouters, 2009: Partitioning recent Greenland mass loss. Science, 326, 984-986, https://doi.org/ 10.1126/science.1178176.

Wåhlin, A., X. Yuan, G. Björk, and C. Nohr, 2010: Inflow of warm Circumpolar Deep Water in the central Amundsen shelf. J. Phys. Oceanogr., 40, 1427-1434, https://doi.org/ 10.1175/2010JPO4431.1. 